CAROLINE PEREIRA DA COSTA

Influência da via de sinalização HIPPO na segregação entre a massa interna celular e o trofectoderma em embriões bovinos

São Paulo

2020 


\section{Influência da via de sinalização HIPPO na segregação entre a massa interna celular e o trofectoderma em embriões bovinos}

Dissertação apresentada ao Programa de PósGraduação em Reprodução Animal da Faculdade de Medicina Veterinária e Zootecnia da Universidade de São Paulo para a obtenção do título de Mestre em Ciências.

\section{Departamento:}

Reprodução Animal

Área de concentração:

Reprodução Animal

\section{Orientador:}

Prof. Dr. Marcelo Demarchi Goissis

São Paulo 
Autorizo a reprodução parcial ou total desta obra, para fins acadêmicos, desde que citada a fonte.

\section{DADOS INTERNACIONAIS DE CATALOGAC̣ÃO NA PUBLICAC̣̃̃o}

(Biblioteca Virginie Buff D'Ápice da Faculdade de Medicina Veterinária e Zootecnia da Universidade de São Paulo)

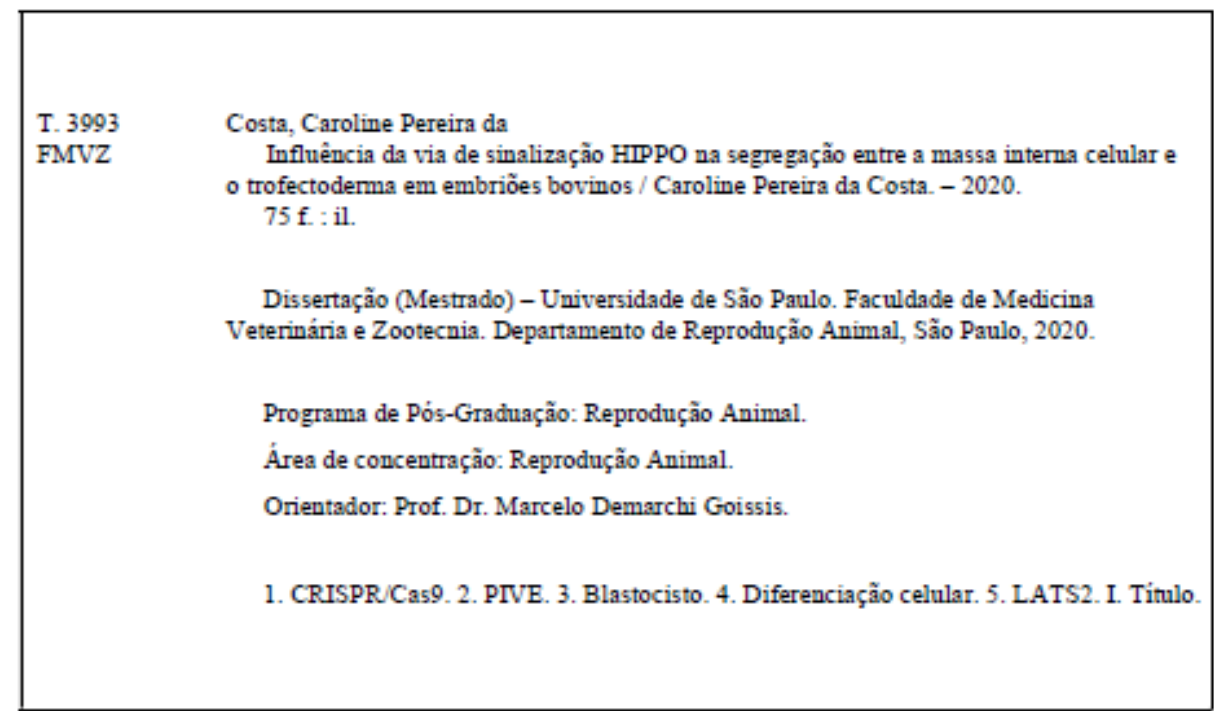

Ficha catalografíca elaborada pela babliotecíria Maria Aparecida Laet, CRB 5673-8, da FMVZUSP. 


\section{CERTIFICADO}

Certificamos que a proposta intitulada "Influência da via de sinalização HIPPO na segregação entre a massa interna celular e o trofectoderma em embriठ̄es bovinos", protocolada sob o CEUA $n^{2} 7341170818$ (ID cos813), sob a responsabilidade de Marcelo Demarchi Goissis e equipe; Caroline Pereira da Costa - que envolve a produçăo, manutenção e/ou utilizaçăo de animais pertencentes ao filo Chordata, subfilo Vertebrata (exceto o homem), para fins de pesquisa científica ou ensino - está de acordo com os preceitos da Lei 11.794 de 8 de outubro de 2008, com o Decreto 6.899 de 15 de julho de 2009 , bem como com as normas editadas pelo Conselho Nacional de Controle da Experimentaçăo Animal (CONCEA), e foi aprovada pela Comissão de Ética no Uso de Animais da Faculdade de Medicina Veterinária e Zootecnia da Universidade de São Paulo (CEUA/FMVZ) na reuniăo de 21/11/2018.

We certify that the proposal "Influence of the HIPPO signaling pathway on the segregation between the inner cell mass and the trophectoderm in bovine embryos ", utilizing 751 Bovines (1 males and 750 females), protocol number CEUA 7341170818 (ID 005813), under the responsibility of Marcelo Demarchi Goissis and team; Caroline Pereira da Costa - which involves the production, maintenance and/or use of animals belonging to the phylum Chordata, subphylum Vertebrata (except human beings), for scientific research purposes or teaching - is in accordance with Law 11.794 of October 8, 2008, Decree 6899 of July 15, 2009, as well as with the rules issued by the National Council for Control of Animal Experimentation (CONCEA), and was approved by the Ethic Committee on Animal Use of the School of Veterinary Medicine and Animal Science (University of São Paulo) (CEUA/FMVZ) in the meeting of $11 / 21 / 2018$.

Finalidade da Proposta: Pesquisa

Vigência da Proposta: de 09/2018 a 09/2020_Área: Reproduçăo Animal

Origem: Animais provenientes de estabelecimentos comerciais

Espécie: Bovinos sexo: Machos idade: 2 a 10 anos $\quad$ N: 1

Linhagem: Bos taurus indicus

Peso: $\quad 400$ a $800 \mathrm{~kg}$

\begin{tabular}{lllll}
\hline Origem: & Animais provenientes de estabelecimentos comerciais & & & \\
Espécie: & Bovinos & sexo: Fêmeas & idade: 2 a 10 anos & $N$ N: \\
Linhagem: & Bos taurus indicus & Peso: $300 \mathrm{a} 600 \mathrm{~kg}$ & \\
\hline
\end{tabular}

Local do experimento: Departamento de Reproduçã̃o Animal FMVZ/USP São Paulo-SP.

São Paulo, 22 de novembro de 2018

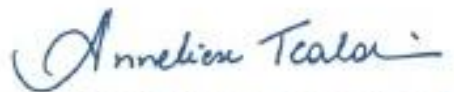

Profa. Dra. Anneliese de Souza Traldi

Presidente da Comissão de Ética no Uso de Animais

Faculdade de Medicina Veterinária e Zootecnia da Universidade de Săo Paulo

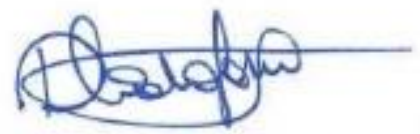

Roseli da Costa Gomes Secretária

Faculdade de Medicina Veterinária e Zootecnia da Universidade de Săo Paulo 


\section{FOLHA DE AVALIAÇÃO}

Autor: DA COSTA, Caroline Pereira

Título: Influência da via de sinalização HIPPO na segregação entre a massa interna celular e o trofectoderma em embriões bovinos

Dissertação apresentada ao Programa de Pós-

Graduação em Reprodução Animal da Faculdade de Medicina Veterinária e Zootecnia da Universidade de São Paulo para obtenção do título de Mestre em Ciências.

Data:

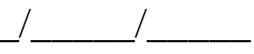

\section{Banca Examinadora}

Prof. Dr.

Instituição: Julgamento:

Prof. Dr.

Instituição: Julgamento:

Prof. Dr.

Instituição: Julgamento: 


\section{DEDICATÓRIA}

Dedico aos meus pais Walter e Jacira, por serem detentores de uma sabedoria que não vem dos livros.

Dedico a Julia Rosenberg Pearson (In memoriam). 


\section{AGRADECIMENTOS}

Primeiramente a Deus, por me permitir acordar todos os dias e me guiar em busca dos meus objetivos.

Aos meus pais, Walter e Jacira, pelo exemplo de determinação, superação e honestidade. Por terem sido minha base e meu amparo durante toda a minha vida. A minha irmã Tatiane pelas longas conversas e eterna parceria. Amo vocês.

Ao meu noivo Thiago por ser "meu braço direito", confidente, fiel ouvinte e por sempre me apoiar, independentemente da situação. É sempre bom ter um ombro amigo.

Ao professor Pietro Sampaio Baruselli, por ter sido o precursor da minha chegada até a USP, por ter me recebido e instruído em 2018. Ao professor Marcelo Demarchi Goissis pela oportunidade de realização do Mestrado e pela orientação, e a todos os mestres, que durante a minha formação me impulsionaram ao saber.

Aos Engenheiros Celso Carlos Buglione Neto e André Luiz Watanabe, exorientadores de estágio e a toda a equipe da Itaipu Binacional, que em 2017 me mostraram o caminho correto para a escrita e por me projetarem para a pesquisa, vocês fazem parte disso.

A Fundação de Amparo à Pesquisa do Estado de São Paulo (FAPESP) pelo apoio financeiro ao projeto, processo 2018/18924-8.

Por último e não menos importante, a todos os animais que de alguma forma passaram pelas minhas mãos durante toda a minha formação. Vocês me tornam uma pessoa melhor a cada dia. 
"Feliz é aquele que consegue conhecer as causas das coisas." - Virgílio 


\section{RESUMO}

DA COSTA, C. P. Influência da via de sinalização HIPPO na segregação entre a massa interna celular e o trofectoderma em embriões bovinos. 2020. 75f. Dissertação (Mestrado em Ciências) - Faculdade de Medicina Veterinária e Zootecnia, Universidade de São Paulo, São Paulo, 2020.

O primeiro evento de diferenciação celular em mamíferos consiste na separação entre a massa celular interna (MCI) e o trofectoderma (TE). Em camundongos, a via de sinalização HIPPO atua no controle da expressão de genes que definem essa diferenciação. Em bovinos, há indícios que os mesmos genes não participam da mesma maneira, porém a via HIPPO pode estar implicada nesse evento biológico. No presente estudo buscou-se testar a hipótese de que a atividade da proteína quinase LATS2 é necessária para a diferenciação da MCI em embriões bovinos. Para isso, realizou-se edição gênica via sistema CRISPR/Cas9 com intuito de inibir a função quinase de LATS2. Zigotos bovinos produzidos in vitro foram microinjetados com RNAs guia para o gene LATS2 acrescidos da enzima de restrição Cas9. Os zigotos foram separados em 3 grupos experimentais, sendo: grupo controle (não microinjetado), grupo Cas9 (microinjetado apenas com a proteína Cas9) e grupo gRNA (microinjetado com dois RNAs guias para o gene LATS2 e proteína Cas9). Os embriões foram cultivados para avaliação da taxa de formação de blastocistos, distribuição celular e fixados em paraformol 3,8\% para posterior realização da imunofluorescência para YAP, seguido de avaliação de genótipo. Os resultados obtidos sugeriram que a clivagem não foi afetada no grupo editado, sendo as taxas $58 \%, 36 \%$ e $50 \%$ para grupo controle, Cas9 e gRNA respectivamente; porém, as taxas de formação de blastocisto sugeriram uma interferência direta no grupo editado, sendo 30\%, $10 \%$ e $6 \%$ respectivamente, para os grupos controle, Cas9 e gRNA. Observou-se no âmbito morfológico que os embriões do grupo gRNA aparentavam estruturas assemelhadas a mórulas, sugestivo de morte embrionária ou bloqueio da diferenciação nessa fase do desenvolvimento. Houve redução numérica no número de células nas estruturas do grupo gRNA. As imagens obtidas via microscopia confocal, após a realização de imunofluorescência para YAP, demonstram a marcação de células do TE nos embriões microinjetados apenas com Cas9 e controle, porém, essa marcação não ocorreu nas no grupo gRNA em embriões que não formaram blastocele. Após a extração individual de DNA dos embriões testados na imunofluorescência, a PCR da região alvo de LATS2 resultou em uma banda de 478pb, além da banda original de 650pb, em uma amostra do grupo gRNA. Após sequenciamento dos produtos de PCR pelo método Sanger, constatou-se a alteração genética 
oriunda da deleção de trecho do gene LATS2 em 2 embriões, demonstrando o sucesso da edição gênica e corroborando com os demais achados. Isso sugere que a via HIPPO possui papel significativo na diferenciação de MCI e TE em embriões bovinos e de que o gene LATS2 está ligado à formação de blastocistos na espécie bovina.

Palavras-chave: CRISPR/Cas9. LATS2. Blastocisto. Diferenciação celular. 


\begin{abstract}
DA COSTA, C. P. Influence of HIPPO signaling pathway on segregation between internal cell mass and trophectoderm in bovine embryos. 2020. 75p. Dissertation (Master of Science) - Faculdade de Medicina Veterinária e Zootecnia, Universidade de São Paulo, São Paulo, 2020.
\end{abstract}

The first cellular differentiation event in mammals consists of the separation between the internal cellular mass (ICM) and the trophectoderm (TE). In mice, the HIPPO signaling pathway acts to control the expression of genes that define this differentiation. In cattle, there are indications that the same genes do not participate in the same way, but the HIPPO pathway may be involved in this biological event. In the present study we aimed to test the hypothesis that the activity of LATS2 kinase is necessary for the differentiation of ICM in bovine embryos. In order to achieve this, we employed CRISPR/Cas9 gene editing system to inhibit the kinase function of LATS2. In vitro produced bovine zygotes were microinjected with RNAs guide aiming the LATS2 gene plus Cas9 restriction enzyme. The zygotes were sorted in 3 experimental groups: control group (not microinjected), Cas9 group (microinjected only with Cas9 protein) and gRNA group (microinjected with guide RNAs aiming the LATS2 gene and Cas9 protein). The embryos were cultured to evaluate the rate of blastocysts formation, cellular distribution, then fixed in $3.8 \%$ paraformol for subsequent immunofluorescence for YAP, followed by genotyping. The results suggested that the cleavage was not affected in the edited group, as rates were 58\%, 36\% and 50\% for control, Cas9 and gRNA groups respectively; however, the blastocyst formation rates suggested a direct interference in the edited group, being 30\%, 10\% and 6\% respectively, for the control groups, Cas9 and gRNA. Morphologically, it was observed that the embryos of the gRNA group appeared as morulas, suggestive of embryonic death or inhibition of differentation in this phase of development. There was a numeric reduction in total cell count in the structures of the gRNA group. The images obtained via confocal microscopy, after performing immunofluorescence for YAP demonstrate the marking of cells of the TE and MCI in the microinjected embryos only with Cas9 and control, however, this marking did not occur in the microinjected structures that did not form a blastocoel. After individual DNA extraction from the embryos tested in immunofluorescence, PCR of the LATS2 target region resulted in a band of $478 \mathrm{pb}$, in addition to the original $650 \mathrm{pb}$ band, in one sample of the gRNA group. After Sanger sequencing of PCR products, genetic alteration derived from deletion of part of the LATS2 gene was observed in 2 embryos, demonstrating gene editing success and 
corroborating the findings. This suggests that HIPPO pathway has a significant role in the differentiation of MCI and TE in bovine embryos and that the LATS2 gene is linked to the formation of blastocysts in bovine species.

Keywords: CRISPR/Cas9. LATS2. Blastocyst. Cell differentiation. 


\section{LISTA DE FIGURAS}

Figura 1 - Esquema ilustrado do funcionamento do sistema CRISPR/Cas9 ........... 25

Figura 2 - Modelo hipotético gráfico

Figura 3 - Esquema ilustrativo de edição gênica para inativação do domínio quinase de LATS2. .38

Figura 4 - Confirmação de clonagem de sequência de gRNA no plasmídeo pX330

por PCR

Figura 5 - Imagens de embriões dos três grupos experimentais no D8 de cultivo in vitro

Figura 6 - Embriões injetados com LATS2 gRNA corados com 10 $\mu \mathrm{g} / \mathrm{ml}$ Hoechst 33342 (Sigma) após 8 dias de cultivo in vitro (aumento 200x).

Figura 7 - Imunofluorescência para YAP em microscopia confocal .49

Figura 8 - Resultado de genotipagem da região gênica de LATS2 por PCR .50

Figura 9 - Alinhamento das sequências dos produtos de genotipagem por PCR. 


\section{LISTA DE TABELAS}

Tabela 1 - Sequências de oligonucleotídeos utilizadas neste estudo............................40

Tabela 2 - Taxas de clivagem, formação de blastocistos e desenvolvimento das 3 primeiras replicatas. 46

Tabela 3 - Taxas de clivagem, formação de blastocistos e desenvolvimento, oriundos da segunda fase de manipulações..

Tabela 4 - Taxas de clivagem, formação de blastocistos e desenvolvimento, oriundos da terceira fase de manipulações. 53 


\section{LISTA DE GRÁFICOS}

Gráfico 1 - Média das taxas de clivagem, blastocisto e desenvolvimento das primeiras

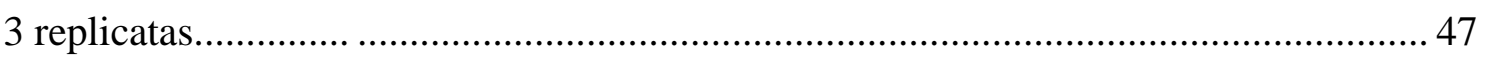

Gráfico 2 - Contagem de células após coloração por hoechst nos embriões acima de 16 células microinjetados às $10 \mathrm{~h}$ após a inseminação in vitro.............................................53 


\section{LISTA DE ABREVIATURAS E NOMENCLATURAS}

PIVE - Produção in vitro de embriões

MIV - Maturação in vitro

FIV - Fertilização in vitro

CIV - Cultivo in vitro

MCI - Massa celular interna

TE - Trofectoderma

HIPPO - Via de sinalização hipopótamo

YAP - Yes-associated protein

LATS - Large Tumor Suppressor Kinase

PCR - Reação em cadeia da polimerase

CRISPR - Repetições palindrômicas curtas agrupadas e regularmente interespaçadas

Cas9 - Enzima de corte associada ao sistema CRISPR para edição gênica

gRNA1 e gRNA2 - RNAs guia de regiões alvo do gene LATS2

gRNA e1, e2 e e3 - Amostras de embriões microinjetados para edição gênica via sistema CRISPR/Cas9 utilizados neste estudo

Nomenclaturas para Bovinos:

Gene - Maiúsculo e itálico

Proteína - Maiúsculo

Nomenclaturas para camundongos:

Gene - Minúsculo e itálico

Proteína - Maiúsculo 


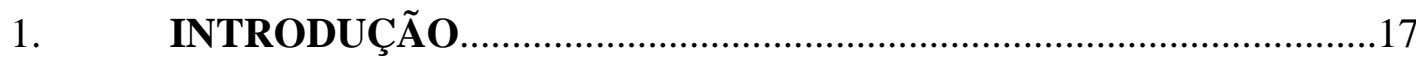

2. CAPÍTULO 1 - REVISÃO DE LITERATURA SOBRE O SISTEMA

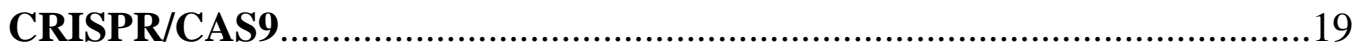

2.1 Sistema CRISPR/Cas9 e suas aplicações na cadeia produtiva animal............19

3. CAPÍTULO 2 - DELEÇÃO DE LATS2 EM EMBRIÕES BOVINOS

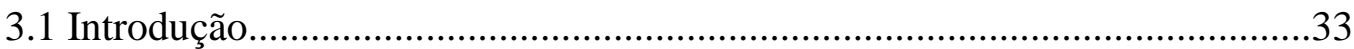

3.1.1 Eventos iniciais do desenvolvimento embrionário de

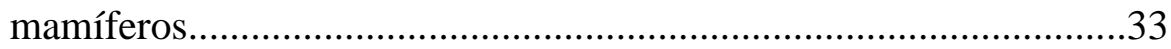

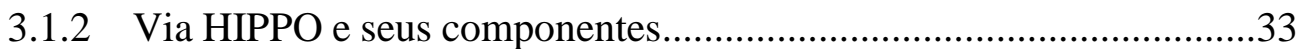

3.1.3 Participação do gene LATS no desenvolvimento embrionário.............35

3.1.4 Via HIPPO em bovinos.......................................................................

3.2 HIPÓTESE

3.3 OBJETIVOS

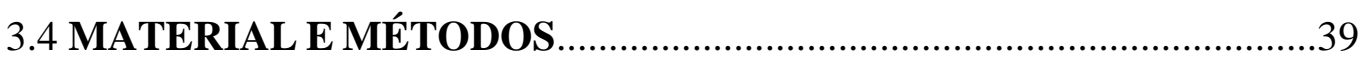

3.4.1 Local do experimento e período de execução.....................................39

3.4.2 Delineamento experimental............................................................39

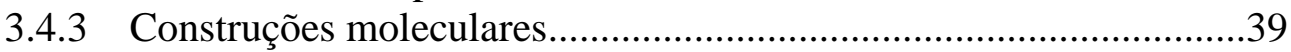

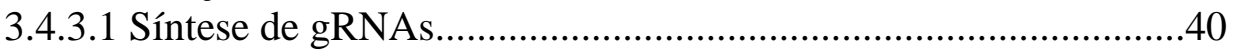

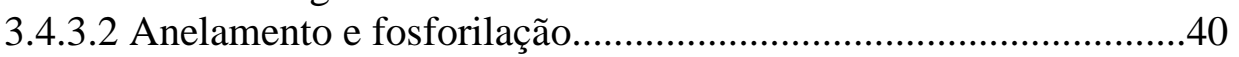

3.4.3.3 Clonagem: digestão plasmidial, purificação, ligação e transformação bacteriana............................................................41

3.4.3.4 Extração de DNA plasmidial...........................................................41

3.4.4 Síntese in vitro dos gRNAs............................................................42

3.4.5 Produção in vitro de embriões bovinos................................................42

3.4.6 Microinjeções em zigotos bovinos......................................................43

3.4.6.1 Microinjeções em oócitos maduros (MII)....................................44

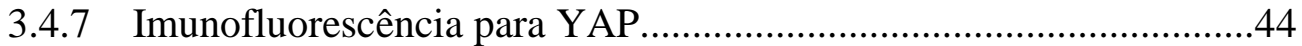

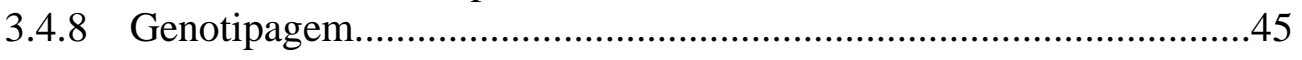

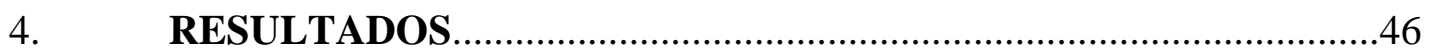

4.1 Avaliações durante o cultivo embrionário - Primeira fase de manipulações...46

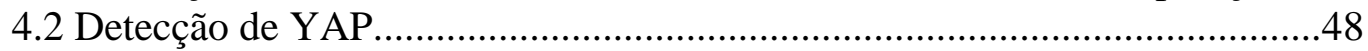

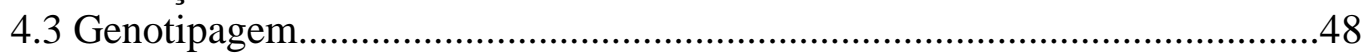

4.4 Sequenciamento pelo método Sanger.............................................................50

4.5 Repetição do experimento pós-quarentena da COVID-19...............................52

5. DISCUSSÃO

6. CONCLUSÃO

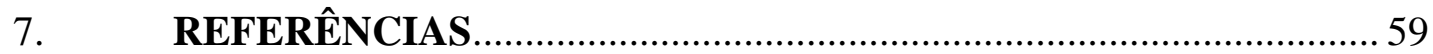

8. ANEXOS

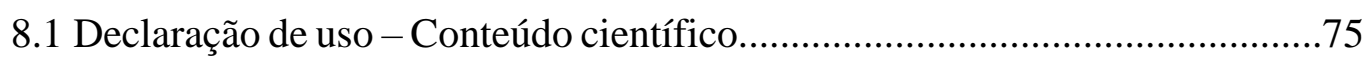




\section{INTRODUÇÃO}

O Brasil é detentor do segundo maior rebanho bovino no mundo. Atualmente, as biotecnologias da reprodução como a inseminação artificial, coleta e transferência de embriões in vivo e a produção in vitro de embriões (PIVE) são bastante difundidas. Entretanto a PIVE ainda demonstra taxas de prenhez inferiores à transferência de embriões in vivo. Isso se deve possivelmente devido à diminuição da qualidade do embrião sob condições in vitro (Farin et al., 1995). A viabilidade reduzida pode resultar em um aumento na incidência de mortalidade fetal após a transferência de embriões (Schmidt et al., 1996). Apesar dos avanços obtidos nos últimos anos com a PIVE e a sua utilização crescente em programas de melhoramento genético bovino, a proporção de embriões que atingem o estágio de blastocisto é raramente superior a 40\% e com índices de gestação em torno, também, de 40\% (Neves et al., 2010). Esses resultados provavelmente se devem às diferenças em várias características observadas entre os embriões produzidos in vitro e os produzidos in vivo (Neves et al., 2010). Estudos sobre a biologia do embrião, mais especificamente sobre mecanismos de diferenciação celular, podem ajudar a compreender potenciais motivos de falhas na implantação e perdas gestacionais iniciais, bem como prover ferramentas para aprimorar a técnica de produção in vitro.

Os primeiros eventos de diferenciação celular em mamíferos ocorrem antes da implantação embrionária e consistem na separação entre a massa celular interna (MCI), que dará origem ao feto propriamente dito, e ao trofectoderma (TE), que dará origem a placenta e anexos. Isto é seguido pela separação entre epiblasto e endoderma primitivo, que ocorre dentro da massa celular interna. Os mecanismos moleculares que controlam essa diferenciação podem envolver desde polarização celular à expressão temporal de fatores de transcrição específicos. Sabe-se em camundongos que a via de sinalização HIPPO, em especial a proteína quinase LATS2, tem papel importante no controle da expressão de genes que definem a segregação entre a MCI e o TE (Yagi et al., 2007; Nishioka et al., 2008; Nishioka et al. 2009). Em bovinos, há indícios que os mesmos genes não participam da mesma maneira, porém a via HIPPO ainda pode estar implicada nesse evento biológico.

Esta dissertação teve como objetivo testar a hipótese de que a atividade de LATS2 é necessária para a diferenciação da MCI em embriões bovinos. Para isto, optamos em usar a tecnologia de edição gênica por CRISPR/Cas9 (Jinek et al. 2012, Cong et al. 2013). Essa técnica permite deleções e facilita inserções em locais específicos do genoma. O histórico, princípios e possíveis aplicações da técnica foram revisados, juntamente com estudos 
constantes sobre a via HIPPO e o gene LATS2, e estão inseridos na revisão de literatura desta dissertação, constantes no capítulo I e II.

Posteriormente, no capítulo II, há a descrição dos experimentos, os quais envolveram a produção in vitro de embriões bovinos, edição gênica mediada por CRISPR/Cas9 e verificação da taxa de formação de blastocistos, contagem de células, imunofluorescência e genotipagem. Portanto, o objetivo foi tentar compreender como a via HIPPO participa na segregação entre a MCI e o TE por meio da deleção gênica de LATS2. Desta maneira, o trabalho poderá contribuir com o entendimento da diferenciação das células durante o desenvolvimento embrionário inicial em bovinos. 


\section{CAPÍtULO I - REVISÃO DE LITERATURA SOBRE O SISTEMA CRISPR/CAS9}

A tecnologia de edição gênica CRISPR/Cas9 foi revisada de maneira global, expondose possíveis utilizações da ferramenta na reprodução animal. A abordagem do sistema CRISPR se dará em formato de artigo de revisão, seguindo regras de formatação semelhantes a revista para qual o artigo foi submetido para publicação.

\subsection{Sistema CRISPR/Cas9 e suas aplicações na cadeia produtiva animal}

CRISPR/Cas 9 system and its applications in the animal production chain

\section{Caroline Pereira da Costa, Mayra Elena O. A. Assumpção, Marcelo Demarchi Goissis.}

Faculdade de Medicina Veterinária e Zootecnia, Universidade de São Paulo, Departamento de Reprodução Animal (VRA), São Paulo - SP.

\section{Resumo}

O melhoramento genético tem papel fundamental no aumento da eficiência da produção pecuária. Entretanto, programas tradicionais de melhoramento podem levar vários anos para atingir um determinado objetivo. Novas abordagens genômicas permitem acelerar esse processo e recentemente a edição gênica surgiu como nova alternativa, além de ter potencial para induzir outras modificações genéticas de interesse comercial e biomédico. A possibilidade de editar o genoma de diferentes espécies, de maneira simples e eficaz, tornouse possível com a tecnologia do sistema CRISPR/Cas9. Esse sistema biológico foi identificado em bactérias e funciona como um mecanismo natural de defesa desses organismos. Baseando-se nos princípios biológicos, cientistas adaptaram esse sistema para atuar em células de mamíferos, incluindo humanas. Trabalhos científicos demonstraram a aplicabilidade da técnica, que permite novas abordagens na condução de estudos da função gênica, além de permitir diferentes experimentos de alteração específica da sequência do DNA. Do ponto de vista da produção animal, a utilização do sistema CRISPR traz novos conceitos e possibilidades para o melhoramento genético, tornando-o mais rápido, mais específico e capaz de gerar novos produtos. O objetivo desta revisão é discutir os princípios da metodologia, associando resultados previamente conhecidos à possíveis aplicações com enfoque na cadeia produtiva animal. 
Palavras-chave: edição gênica, genoma, melhoramento genético, produção animal.

\begin{abstract}
Genetic improvement has a prominent role in increasing the efficiency of livestock production systems. However, traditional breeding programs may take several years to achieve a specific goal. New genomic approaches could accelerate this process and recently gene editing appeared as an alternative and still holds the potential to induce genetic alterations of commercial and biomedical interest. The possibility of editing the genome of different species, in a simple and effective way, became possible with the technology of the CRISPR / Cas9 system. This biological system was identified in bacteria and works as a natural defense mechanism for these organisms. Based on biological principles, scientists adapted this system to act on mammalian cells, including humans. Scientific studies demonstrated the applicability of the technique, which allows new approaches in conducting studies of gene function, in addition to different experiments of targeted modification of the DNA sequence. From the point of view of animal production, the use of the CRISPR brings new concepts and possibilities for genetic improvement, making it faster, more specific and capable of generating new products. The purpose of this review is to discuss the principles of the methodology, associating previously known results to possible applications focusing on the animal production chain.
\end{abstract}

Keywords: genomic editing, genome, genetic improvement, animal production.

\title{
Introdução
}

A produção de alimentos deve aumentar em aproximadamente $50 \%$ nos próximos 30 anos para atender às demandas do crescimento populacional com maior ingestão de proteína de origem animal e, não obstante, com a diminuição dos impactos ambientais (FAO, 2017). O melhoramento genético animal tem grande relevância no sucesso e na eficiência de sistemas de produção animal. Cruzamentos de indivíduos com melhor performance são realizados desde antes dos conhecimentos científicos sobre evolução, genética e herdabilidade (Hill, 2014). Com o advento de novas tecnologias genéticas, os programas de melhoramento incorporaram a seleção genômica para acelerar o ganho de performance (Georges et al. 2019), havendo a possibilidade de inclusão de engenharia genética na modificação do genoma.

Cada célula de um organismo contém uma cópia de todo o genoma. Em humanos são mais de 20.000 genes, três bilhões de pares de bases de DNA, sendo esse número variável de 
espécie para espécie. O DNA consiste em duas fitas, torcidas em uma dupla hélice, mantidas juntas por uma regra de emparelhamento simples, na qual as bases púricas adenina e guanina ligam-se às bases pirimidinas timina e citosina, respectivamente. Os genes determinam as espécies, o organismo, o indivíduo e também fatores relacionados a saúde do indivíduo. Devido aos avanços no sequenciamento de DNA, foi possível identificar genes que predispõem ao risco de surgimento de doenças até genes que interferem diretamente nas qualidades desejáveis para espécies comerciais. Alterar genes nas células vivas de modo específico e de baixo custo na maioria das espécies era um grande desafio, até que, recentemente, um novo método foi descoberto, permitindo a ampliação da capacidade de editar o DNA de múltiplas espécies, incluindo humanos.

A capacidade de deleção, inserção ou incorporação de um gene em um locus específico é uma metodologia extremamente útil para a ciência, seja para estudos de função biológica, detecção de mecanismos infecciosos, diagnóstico de doenças ou ainda, otimização de processos biotecnológicos (Gonçalves \& Paiva, 2017). Até recentemente, a manipulação genética na maioria das espécies tendia a ser inespecífica, ineficiente e de alto custo. Por exemplo, a microinjeção pronuclear em camundongos causa inserções aleatórias (Brinster et al. 1985, Chan et al. 1999) e é de difícil execução em espécies domésticas, devido ao alto conteúdo lipídico dos zigotos, fato que dificulta a visualização dos pronúcleos (McEvoy et al., 2000). Ainda, a produção de animais geneticamente alterados com células-tronco embrionárias tem alto custo e há a dificuldade de obtenção de linhagens dessas células em espécies domésticas (Cibelli et al. 1998, Vackova et al. 2007, Cao et al. 2009, Tan et al. 2011, Bogliotti et al. 2018). Atualmente, a tecnologia CRISPR/Cas9 permite alterações direcionadas no genoma, popularizando os experimentos de deleção (knock-out) ou inserção (knock-in) de genes dentro da biologia molecular moderna (Vora et al., 2016).

CRISPR é um acrônimo de "clustered regularly interspaced short palindromic repeats", ou seja, repetições palindrômicas curtas, agrupadas e regularmente interespaçadas. Essas repetições possuem um eixo de simetria, e, quando lidas na direção oposta, a sequência de bases de uma fita é a mesma da fita complementar, e estão presentes no DNA de aproximadamente $40 \%$ dos genomas bacterianos e em até $90 \%$ das arqueobacterias (Grissa et al., 2007). Essas sequências são acompanhadas por uma outra sequência de DNA chamado de protoespaçador, que consiste em uma região não codificante, inserida no DNA bacteriano após exposição prévia desses microorganismos à genomas invasores, como fagos ou plasmídeos (Barrangou et al., 2007). O sistema CRISPR funciona basicamente como um sistema imunológico de procariotos, visto que é associado à expressão de uma enzima de 
restrição denominada Cas9, cuja ação confere resistência a elementos genéticos exógenos (Brouns et al., 2008). Enquanto o CRISPR armazena as sequências de DNA do agente invasor em sua "memória imunológica", a Cas9 é direcionada para clivar essa determinada região do DNA invasor, com alta especificidade, não havendo aleatoriedade (Wiedenheft et al., 2012).

Ao inserir uma sequência de pares de base de interesse no sistema CRISPR e modificá-lo de modo a replicar essa informação, tornou-se possível aplicar essa maquinaria em genomas de diferentes espécies e realizar a edição gênica de maneira mais simples e mais acessível que outras técnicas como zinc finger nucleases (Urnov et al., 2010, Havlicek et al., 2017) ou TALEN (Zu et al., 2013).

Devido a facilidade, versatilidade e especificidade, em pouco tempo, diferentes estudos foram publicados com a utilização do sistema CRISPR/Cas9 em diversas espécies de plantas e animais com os mais variados objetivos, desde aprimorar a produção de alimentos até criar modelos para estudar doenças humanas. Camundongos (Gao et al., 2018), coelhos (Yuan et al., 2019), cães (Amoasii et al., 2018), porcos (Li et al., 2019), vacas (Bevacqua et al., 2016), peixes (Yeh et al., 2017) e primatas não humanos (Kang et al., 2019) já foram editados geneticamente com êxito, via sistema CRISPR/Cas9. Stadtmauer et al. (2020) demonstraram a viabilidade da edição gênica via sistema CRISPR/Cas9 para imunoterapia contra o câncer, na qual realizaram transferência de células $\mathrm{T}$ editadas para genes tumorais específicos, demonstrando que a tecnologia é segura em humanos.

O objetivo dessa revisão de literatura foi compreender a origem e as diversas aplicações do sistema CRISPR, visando elencar com exemplos os possíveis benefícios e perspectivas futuras para a edição gênica na cadeia produtiva animal.

\section{Origem do Sistema CRISPR/Cas9}

As sequências de DNA que culminaram na tecnologia do sistema CRISPR/Cas9 foram originalmente identificadas no genoma da Escherichia coli em 1987, quando foram descritas como um "elemento de sequência incomum consistindo uma série de repetições de 29 nucleotídeos separadas por sequências únicas de espaçadores de 32 nucleotídeos" (Ishino et al., 1987). Mais tarde, essas sequências foram identificadas em diferentes tipos de bactérias e consequentemente, descrita em diversos estudos, surgindo então a necessidade de nomeá-las: repetições palindrômicas curtas agrupadas e regularmente interespaçadas ou apenas “CRISPR" (Jansen et al., 2002). Além de dar nome às sequências, Jansen et al. (2002) relataram que as sequências CRISPR sempre estavam acompanhadas por uma coleção de genes que foram denominados CRISPR associated genes ou simplesmente Cas. Esses genes 
codificam endonucleases, ou seja, enzimas que podem cortar o DNA. Entretanto, até então não havia sido descoberto um motivo ou uma função pelo qual esses genes sempre estavam associados às sequências CRISPR.

Bolotin et al. (2005), realizando análise in sílico, revelaram três genes associados às estruturas CRISPR em muitas espécies bacterianas. Relataram também a existência de um certo número de espaçadores que possuem homologia principalmente com genes de fagos (vírus que infectam bactérias). Além disso, constataram uma sensibilidade dos fagos relacionada com o número de espaçadores no locus CRISPR da cepa bacteriana, sugerindo que os elementos espaçadores eram traços de invasões passadas por elementos extra cromossômicos. Esses achados levantaram a hipótese de que os elementos espaçadores forneciam imunidade celular, nessas bactérias, contra a infecção por fagos. A presença de grupos de genes Cas próximo às estruturas do CRISPR sugeria que a formação do sistema CRISPR/Cas envolveria uma etapa de degradação do DNA. Baseando-se na estrutura bioquímica das enzimas Cas, análises computacionais predisseram que a ação dessas enzimas se daria após pareamento de RNA com fita de DNA homóloga, levando à quebra do DNA (Makarova et al., 2006).

As propriedades de defesa do sistema CRISPR foram comprovadas biologicamente após verificação da incorporação de sequências virais no genoma bacteriano e consequente aquisição de resistência ao fago, seguida ainda de perda de resistência quando as sequências espaçadoras eram removidas (Gasiunas et al., 2012). Então, alguns laboratórios de biologia molecular, como os de Jennifer Doudna nos Estados Unidos e o de Emmanuelle Charpentier, na época, na Suécia, realizaram estudos voltados especificamente para a ação da CRISPR e da Cas, demonstrando o funcionamento das moléculas de RNA e Cas9 como um sistema, que quando isolado por engenharia genética permitia o corte de sequências específicas de DNA. Em suma, essas investigações trouxeram informações que possibilitaram o entendimento e o subsequente uso do sistema CRISPR/Cas9 para a edição gênica.

\section{Remodelamento do Sistema CRISPR/Cas9}

O CRISPR-Cas9 é uma tecnologia de edição de genoma com grande impacto nas ciências biológicas, pois pode ser projetado e adaptado para cortar, não apenas o DNA viral, mas qualquer sequência de DNA, alterando o RNA guia para corresponder ao alvo do DNA (Jinek et al., 2012). Isso pode ser feito não apenas in vitro, mas também dentro do núcleo de uma célula viva. $\mathrm{O}$ atual sistema CRISPR para aplicações em células eucariotas consiste basicamente em dois componentes: um RNA guia com a sequência gênica de interesse e a 
proteína Cas9, responsável pelo corte do DNA (Jinek et al., 2012, Cong et al., 2013). O RNA guia (gRNA) é um RNA sintético curto, desenhado com a sequência alvo e seguido por uma sequência essencial, conhecida como tracrRNA, necessária para a interação com a Cas9.

Nesse sistema, o gRNA contendo a sequência alvo liga-se à sequência complementar do DNA genômico a ser editado. Esta interação recruta a endonuclease Cas9, que então gera quebras na fita dupla no DNA. Para que esse sistema funcione, há necessidade de ter uma sequência específica adjacente à região alvo a ser clivada pela Cas9. Essa sequência é denominada, do inglês, de protospacer adjacent motif, ou seja, motivo adjacente ao protoespaçador ou apenas PAM sendo este essencial para a clivagem do local de interesse gênico (Palermo et al., 2017). Os RNAs guias podem transportar a Cas9 para qualquer locus do genoma para edição de genes, mas nenhuma edição ocorre, em sequências complementares, sem a presença adjacente do PAM (Anders et al., 2014).

O PAM é uma sequência de DNA de 2 a 6 pares de bases, imediatamente após essa sequência de DNA reconhecida pelo gRNA (Shah et al., 2013), sendo que para a Cas9, essa sequência caracteriza-se por 5'-NGG-3', onde "N" é qualquer base de DNA seguida por duas bases de guanina ("G"). O PAM atua como um componente de direcionamento essencial que distingue o DNA bacteriano do DNA não próprio, impedindo assim, que o locus endógeno que codifica as sequências de gRNA seja destruído pelas enzimas Cas (Mali et al., 2013). A Cas9 não se ligará com êxito ou quebrará a sequência de DNA alvo se não for seguida pelo PAM (Jinek et al., 2012). Com a utilização de simulações de dinâmica molecular, Palermo et al. (2017) encontraram evidências de que o PAM atua como um efetor alostérico de modo a alterar a conformação da Cas9, permitindo que os domínios catalíticos operem para que ocorra a clivagem específica das duas cadeias de DNA

Portanto, a nuclease Cas9 guiada por RNA do sistema imunológico adaptativo do CRISPR, pode ser usada para facilitar a engenharia eficiente do genoma em células eucarióticas, especificando simplesmente uma sequência de direcionamento de 20 nucleotídeos dentro do RNA guia (Ran et al., 2013). A Cas9 descompactará o DNA e o corresponderá ao RNA alvo e se a sequência de interesse for encontrada, a enzima usará uma espécie de "tesoura" molecular para cortar a região do DNA identificada (Fig. 1). 
Figura 1 - Esquema ilustrado do funcionamento do sistema CRISPR/Cas9.

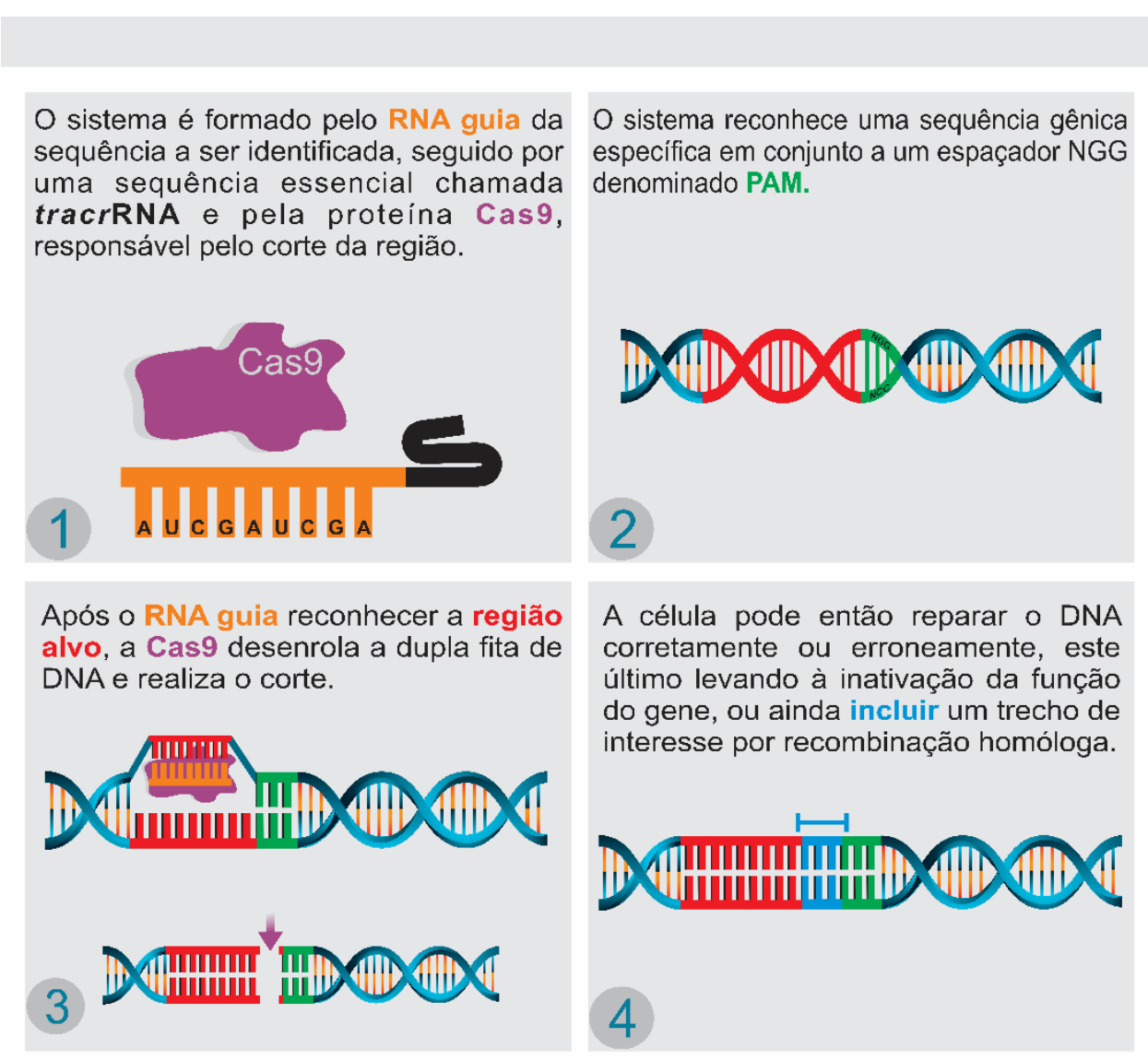

Legenda: 1. Componentes do sistema CRISPR: RNA guia e enzima Cas9. 2. Reconhecimento da sequência alvo seguida do PAM pelo RNA guia. 3. Quebra da dupla fita de DNA pela Cas9. 4. Reparo do DNA pela célula com possibilidade de manutenção, alteração, inclusão ou deleção de sequência.

No momento de corte da região genômica, a célula tenta reparar o local, mas o processo de reparo é propenso a erros, levando a mutações que podem desativar o gene, permitindo então a compreensão da sua função (Swiech et al., 2015). Essas mutações podem ocorrer de maneira aleatória, mas existe ainda a possibilidade de serem guiadas, por exemplo, substituindo um gene mutante que causa doença por uma cópia não patogênica, e isso pode ser feito adicionando uma sequência de DNA doadora que atuará como molde, carregando a sequência desejada (Harmsen et al., 2018). Depois do corte de DNA pela Cas9, o DNA doador pode emparelhar com as pontas cortadas, recombinando e substituindo a sequência original. Esse processo pode ser realizado em cultivo celular, incluindo células tronco, que podem dar origem à diferentes tipos de células e também em zigotos, permitindo a criação de animais editados e geneticamente modificados com mutações direcionadas. Diferente dos outros métodos que também objetivavam a edição gênica, o CRISPR pode ser usado para atingir muitos genes de uma só vez (Cong et al., 2013). 
Além disso, é possível alterar sítios catalíticos da enzima Cas9, de modo que passe a se comportar de diferentes formas, como por exemplo, sendo uma nickase (Friedland et al., 2015), na qual corta apenas uma das duas fitas de DNA. Isto permitiu a criação de técnicas como a base editing (edição de base), que permite instaurar diretamente mutações pontuais no DNA celular sem fazer quebras de DNA de fita dupla (Komor et al. 2016). Anzalone et al. (2019) demonstraram um método versátil e preciso de edição de genoma que grava diretamente novas informações genéticas em um local de DNA específico, usando uma endonuclease Cas9 nickase, fundida a uma transcriptase reversa, programada com um RNA guia de edição principal que especifica o local de destino e codifica a edição desejada, permitindo maior gama de alterações com maior precisão no genoma alvo, sendo então denominado prime editing.

O sistema CRISPR/Cas pode ser usado para facilitar a edição de genoma de alta eficiência em mais de um locus em células de mamíferos: usando dois gRNAs. O pesquisador Feng Zhang e colaboradores demonstraram a edição simultânea de loci humanos, com eficiência de 65 a 68\% para cada locus (Cong et al., 2013), e também demonstraram que o sistema CRISPR de Streptococcus pyogenes pode ser remodelado de maneira heteróloga em células de mamíferos, possibilitando a edição eficaz do genoma (Cong et al., 2013, Ran et al., 2013), comprovando o uso do sistema CRISPR/Cas9 como uma eficiente ferramenta para mediar a alteração de diferentes genomas com alta precisão.

Atualmente, existem diversos protocolos para a seleção de sítios de destino, avaliação da eficiência da clivagem e análise de off-targets, ou atividade fora do alvo. Essa seleção pode ser facilitada com a utilização de softwares (Brazelton et al., 2015), que buscam as regiões que tenham a sequência 5'-NGG-3' do PAM próximo ao local de destino, o que é essencial para que o corte ocorra (Palermo et al., 2017). Existem diversos softwares gratuitos disponíveis na internet para seleção de sequências alvo (lista disponível em Guide Design Resources, https://zlab.bio/guide-design-resources). Iniciando os experimentos com CRISPR, a partir do design da região alvo, as modificações genéticas podem ser obtidas entre uma a duas semanas e as linhas celulares clonais modificadas podem ser derivadas em duas a três semanas (Ran et al., 2013, Cong et al., 2013), demonstrando a facilidade do uso dessa ferramenta em comparação às outras disponíveis. Vale ressaltar que atividades fora do alvo podem ocorrer em regiões com similaridade à sequência alvo seguidas do PAM, causando quebras não intencionais em outras regiões do genoma. Portanto, deve-se realizar uma seleção cuidadosa da sequência alvo a ser utilizada. Existem relatos de alterações em grandes porções 
de DNA com uso do CRISPR (Alanis-Lobato et al. 2020), logo estudos visando compreender os efeitos off-targets devem ser realizados para aumentar a especificidade da técnica.

\section{Aplicabilidade da técnica na produção animal}

A possibilidade de se utilizar uma sequência de RNA para guiar o corte de uma região gênica específica, tornou a utilização do sistema uma das mais eficazes ferramentas de edição e engenharia genômica. Através de diferentes estudos e adaptações da técnica, foi possível ampliar a sua aplicabilidade e determinar a sua importância para a pesquisa, visto o Nobel de Química no ano de 2020, atribuído às pesquisadoras Emmanuelle Charpentier e Jennifer Doudna. Os métodos de edição via sistema CRISPR/Cas9 estão sendo aprimorados rapidamente, possibilitando muitas aplicações em pesquisa básica, no desenvolvimento de fármacos (Kasap et al., 2014), para o tratamento de pacientes humanos portadores de doença genética (Stadtmauer et al., 2020) e na indústria alimentícia e na agricultura (Shimatani et al., 2018) .

No cenário atual da produção animal, a utilização da tecnologia de edição gênica permite o estudo de diversos mecanismos que estão relacionados aos índices zootécnicos e ao melhoramento genético de rebanhos, uma busca constante do setor. Neste cenário, a competitividade no mercado agropecuário tornou-se elemento fundamental, tendo em vista a necessidade para o mercado de produtos que sejam de qualidade e apresentem preço acessível ao consumidor final (Filho et al., 2002). Além disso, à utilização de animais como modelos de estudo para humanos vem sendo discutida amplamente, de modo a ser necessário pensar antes de mais nada, no bem-estar dos animais, o que pode ser possibilitado pela técnica (Tu et al., 2015).

Alguns estudos já comprovaram a eficácia da técnica CRISPR/Cas9 em diversas espécies de produção como ovina, peixes e bovina, que serão salientados adiante. Além da busca pelo aumento de produtividade animal com incremento de biotecnologias, vale ressaltar que uma exigência cada vez mais presente na sociedade é a sustentabilidade, levando em consideração a preservação ambiental e maior qualidade de vida aos animais. A tendência é que tal exigência se amplie e envolva toda a cadeia da produção animal e as diferentes espécies envolvidas (Filho et al., 2002, Menchaca et al., 2020).

\section{CRISPR na piscicultura e avicultura}

O comprometimento socioambiental do sistema de produção também vem sendo levado em consideração por produtores e consumidores. O gasto hídrico em áreas de cultivo 
expõe as atividades de produção animal a questionamentos em relação a sua parcela de responsabilidade ambiental. Na produção de peixes, por exemplo, o gasto hídrico é alto, ainda mais em espécies com período de cultivo longo. Kishimoto et al. (2018) utilizaram a tecnologia CRISPR para deletar o gene da miostatina (Mstn) em peixes da espécie Pagrus major, e, obtiveram animais atingindo precocemente o peso ao abate, com maior aproveitamento de filé e com o desenvolvimento de uma estrutura óssea maior, quando comparada aos peixes convencionais da espécie. Com a produção de Pagrus major editado, o tempo de cultivo até o abate reduz, e consequentemente, o gasto hídrico da atividade também.

$\mathrm{Na}$ avicultura, os problemas com a sanidade são responsáveis por grandes perdas econômicas na atividade. Os retrovírus são um dos patógenos mais difíceis de serem

controlados por estratégias convencionais, como as vacinas (Hellmich et al., 2020). O subgrupo "J" do vírus da leucose aviária (ALV-J) é um retrovírus oncogênico e imunossupressor que causa leucose mielóide e outros tumores em galinhas. Hellmich et al. (2020) obtiveram resistência ao ALV-J em uma linha comercial de frangos por exclusão precisa de um locus receptor do vírus, utilizando o sistema CRISPR/Cas9. A modificação genética protegeu completamente as células da infecção e não teve efeito negativo no desenvolvimento e nas condições gerais de saúde das galinhas editadas. No geral, a geração de aves resistentes ao ALV-J por edição precisa de genes demonstra o imenso potencial dessa abordagem como uma estratégia alternativa de controle de doenças em aves.

\section{CRISPR e os índices zootécnicos}

Pesquisas recentes demonstram que a produtividade animal pode ser alterada de maneira a melhorar os índices zootécnicos com a tecnologia CRISPR/Cas9. Li et al. (2019), com o intuito de melhorar o rendimento do cashmere de alto valor, inseriram em cabras-decaxemira, o gene TR4 (timosina beta 4) usando a tecnologia CRISPR/Cas9. Este gene está envolvido na migração de células-tronco e promove o crescimento do pelame. As cabras exibiram um aumento no rendimento do cashmere em 74,5\%, sem alterações na espessura e qualidade do fio. O sistema CRISPR/Cas9 também foi utilizado para editar o gene Mstn que codifica a miostatina em ovelhas, gerando animais knock-out com o objetivo de promover maior desenvolvimento cárneo em animais selecionados originalmente para produção de lã, gerando animais com dupla aptidão (Crispo et al., 2015). As análises do estudo confirmaram a ausência de miostatina, mostrando maior peso corporal em cordeiros oriundos de zigotos microinjetados com CRISPR/Cas9 (Crispo et al., 2015). 


\section{Edição gênica, saúde e bem-estar animal}

Em relação ao bem-estar de animais de produção, as tecnologias de edição gênica também já foram empregadas, objetivando a otimização da qualidade de vida desses animais, minimizando procedimentos dolorosos. Práticas de interrupção do crescimento dos botões de chifre, conhecido como amochamento ou de remoção de chifres, conhecido como descorna, em gado, têm recebido atenção em relação a questões de bem-estar animal (Bond et al., 2012). Além disso, animais sob condições de dor, estresse e desconforto não agregam valor zootécnico a produção, visto que não conseguem adquirir peso ou se reproduzirem e podendo ainda, influenciar nos sistemas produtivos pecuários e no produto final, seja a carne bovina ou o leite (Oliveira et al., 2008). A remoção do chifre é feita para melhorar a segurança dos manipuladores humanos, diminuir o risco de ferimentos entre um animal e outro devido a comportamentos agressivos e reduzir a incidência de desperdício de carcaça devido a contusões (Bond et al., 2012). Carlson et al. (2016) demonstraram a utilização da técnica de edição gênica TALEN, em bovinos, para editar o gene de crescimento de chifres em gado leiteiro. A utilização da tecnologia CRISPR/Cas9 também pode ser utilizada em projetos com intuitos semelhantes. O uso de edição gênica permitiria que a maioria do rebanho apresentasse o alelo "mocho" mais rapidamente e com menor endogamia do que com programas convencionais de melhoramento genético (Mueller et al. 2019). Portanto, as ferramentas de edição gênica se tornam um grande aliado na resolução de problemas como este.

Pensando em uma outra abordagem, reduzir a incidência de doenças pode aumentar a produtividade, o bem estar animal e a saúde humana. Bevacqua et al. (2016) utilizaram o sistema CRISPR/Cas9 com o objetivo de induzir alelos knockout e knock-in do gene PRNP bovino, responsável pela encefalopatia espongiforme bovina, conhecida popularmente como “doença da vaca louca”. Os resultados relatam que o sistema CRISPR/Cas9 é eficiente para induzir indels, que são pequenas inserções ou deleções no genoma, do gene PRNP em células bovinas cultivadas e embriões. Tal abordagem poderia ter um grande impacto no desenvolvimento de animais resistentes a essa e outras importantes doenças zoonóticas, visando a resolução de problemas de saúde pública no mundo todo. Em relação a saúde animal, sabe-se que a seleção fenotípica durante a domesticação, resultou na incorporação indesejada de mutações deletérias. Em cavalos, a condição autossômica recessiva conhecida como enzima ramificadora de glicogênio deficiente é o resultado de uma destas mutações. Pinzon-Arteaga et al. (2020) utilizaram a recombinação homóloga via CRISPR/Cas9 para corrigir a mutação em uma linha celular primária de fibroblastos, derivada de um garanhão heterozigótico de alto mérito genético. A distância entre a ruptura de fita dupla mediada por 
Cas9 e o local da mutação foram os principais determinantes para a edição bem-sucedida. Isso demonstra a gama de aplicações do sistema CRISPR/Cas9 para corrigir outras doenças genéticas em populações animais.

\section{CRISPR e o xenotransplante}

A cadeia produtiva animal possui grande representatividade no setor alimentício e de subprodutos, e muitas vezes, apenas a produção de carne e leite são lembradas. Contudo, a semelhança fisiológica e morfológica de órgãos, caracteriza algumas espécies como importantes no estudo de doenças em humanos ou ainda, de xenotransplantes, visto que a criação in vitro de órgãos ou tecidos de tamanho humano adequados para transplante de pacientes se mostra, até então de difícil execução (Ezashi et al., 2015). Um dos principais desafios do xenotransplante é a rejeição de órgãos pela resposta imune. Fischer et al. (2016) demonstraram a utilização do sistema CRISPR/Cas9 para superar os mecanismos de rejeição hiperaguda e rejeição vascular aguda no xenotransplante entre suíno e humano, enquanto Niu et al. (2017) utilizaram o sistema para solucionar as incompatibilidades imunológicas e o risco de transmissão de espécies cruzadas de retrovírus endógenos porcinos. Vilarino et al. (2017) "desativaram" o gene PDX1, impedindo a pancreatogênese em ovelhas, visando a produção de órgãos interespecíficos para medicina regenerativa. No futuro, combinar a edição de genes com a complementação de CRISPR/Cas9 e células-tronco pluripotentes pode resultar em uma abordagem poderosa para a geração de órgãos humanos em modelos animais (Vilarino et al., 2017).

\section{Edição gênica, transgênicos e regulamentações}

Os animais transgênicos seguem sendo uma das ferramentas de pesquisa mais importantes das ciências biológicas, pois representam modelos únicos e passíveis de serem personalizados para abordar questões específicas. Portanto, a capacidade de introduzir genes funcionais em animais confere uma estratégia muito poderosa para compreender processos e sistemas biológicos complexos. A transferência de genes é de particular valor em animais de produção, cujos longos ciclos das práticas clássicas de melhoramento genético são reduzidos (Pinkert, 2014). O transgênico é um organismo que possui uma sequência de DNA vinda de outro organismo e apesar de serem considerados por alguns uma metodologia aliada à melhorias no setor agrícola, divide opiniões e está geralmente ligada à questionamentos e receios, principalmente quando se refere a interferência desses organismos na saúde humana. Um dos pontos relevantes abordados, é que os transgênicos poderiam predispor às alergias, 
resistência a antibióticos, alterações no conteúdo nutritivo dos alimentos, além de preocupação pelo uso de vírus nas modificações genéticas (González, 2008).

O CRISPR/Cas9 revolucionou a geração de animais editados. Na agropecuária, a edição gênica permite modificar o genoma de modo a acelerar a introdução de uma variante natural de alelo específico na população alvo (Mueller et al. 2019). Este sistema demonstra eficiência e facilidade de uso sem precedentes, reduzindo o tempo e o custo necessários para a edição do genoma, permitindo a produção de animais com modificações genéticas mais extensas. A técnica do CRISPR permite gerar um organismo geneticamente modificado (OGM), porém não obrigatoriamente transgênico. Transgênicos e OGM_não são sinônimos (Pelaez \& Schmidt, 2000), visto que para o primeiro é necessária a adição de sequências de DNA de organismos distintos.

Em relação ao uso dos transgênicos no mundo, diversos países, como os do continente europeu são bastante enfáticos em relação a proibição ou restrição do uso destes animais na cadeia produtiva (Bonny, 2003). No Brasil, a Lei no 11.105 de 24 de março de 2005 (Brasil, 2005) estabelece normas de segurança e mecanismos de fiscalização de atividades que envolvam organismos geneticamente modificados, por meio da criação da Comissão Técnica Nacional de Biossegurança - (CTNBio). Porém, quando o assunto é edição gênica e o sistema CRISPR, ainda há muito o que ser discutido a cerca do uso dos organismos editados com esta tecnologia. Em 2018, o Tribunal Europeu de Justiça equiparou plantas modificadas com CRISPR a transgênicos convencionais e decidiu que culturas editadas por genes devem estar sujeitas aos mesmos regulamentos rigorosos (Callaway, 2018). No Brasil, a resolução Normativa N $^{\text {}} 24$ da CTNBio, de 07 de janeiro de 2020 (Brasil, 2020) impõe condições para a comercialização de OGM, incluindo animais editados apresentando construção genética idêntica à própria espécie, sendo que esses casos serão avaliados individualmente quanto aos riscos.

Regulamentos restritivos em alguns países são oportunidades para outros e consequentemente, aqueles que hoje restringirem excessivamente o uso de biotecnologias pagarão pelo uso e pelos produtos no futuro (Menchaca et al., 2020). A discussão sobre o uso da técnica deve ser pautada pela segurança às pessoas e ao meio ambiente, de modo a não reduzir a aceitação pela sociedade de uma tecnologia com potencial de impacto econômico e na sustentabilidade das atividades da cadeia produtiva animal. 


\section{Conclusão}

A tecnologia CRISPR/Cas9 demonstra ser aplicável a uma grande variedade de animais, desde metazoários de ramificação precoce até primatas. O sistema permite a construção de modelos precisos de doenças humanas e terapias potenciais foram testadas e validadas em diferentes modelos animais. Com base no progresso notável até o momento, pode-se antecipar que, no futuro, a tecnologia CRISPR/Cas9 permitirá avanços adicionais de longo alcance, incluindo o entendimento de doenças com origens genéticas complexas, a engenharia de animais para produção de órgãos para transplante humano e a transformação genética de populações inteiras de organismos para impedir a propagação de doenças.

A utilização da metodologia em diferentes genomas, aliada à facilidade de aplicação da técnica, já foram comprovados. Além da tecnologia demonstrar ao longo de anos e diferentes estudos a sua funcionalidade, quando trazida para o cenário atual da produção animal, carrega consigo novos conceitos e possibilidades para o melhoramento genético, tornando-o mais rápido, mais específico e capaz de gerar novos produtos. A modernização da edição gênica em animais de produção poderá otimizar significativamente a cadeia produtiva animal no Brasil e no mundo, repaginando a forma de produção de carne, leite e derivados e possibilitando a associação direta do bem-estar em conjunto à elevados índices zootécnicos. 


\section{CAPÍTULO II - DELEÇÃO DE LATS2 EM EMBRIÕES BOVINOS}

\subsection{Introdução}

3.1.1 Eventos iniciais do desenvolvimento embrionário de mamíferos

A formação de blastocistos é o primeiro processo de diferenciação durante o desenvolvimento embrionário em mamíferos, produzindo a MCI e o TE (Frankenberg et al., 2016). As células da MCI contribuem para todos os tecidos embrionários, enquanto as células do TE formam a placenta e anexos externos (Gardner, 1989). Ambas as linhagens celulares são vitais para o desenvolvimento e a sobrevivência embrionária e fetal (Hardy et al., 1989). Koo et al., (2002) fornecem evidências de que biotécnicas como a fecundação in vitro ou transferência nuclear causam alocações desproporcionais de células da MCI e ou TE. Eles obtiveram em sua grande maioria, blastocistos com anormalidades numéricas nas células da MCI e diminuição nas células do TE no estágio pré-implantação.

Durante o período de pré-implantação, o embrião mamífero sofre uma série de alterações moleculares, fisiológicas e metabólicas que transformam um zigoto totipotente de célula única em um blastocisto multicelular composto e diferenciado (Wang \& Dey, 2006). Dada a complexidade molecular de eventos necessários para o desenvolvimento correto, por muitas vezes o embrião mamífero falha até chegar na fase de blastocisto (Ortega et al., 2017). A partir disso, diversos trabalhos foram voltados para o estudo específico de genes, proteínas e vias envolvidas no processo de diferenciação celular embrionária.

\subsubsection{Via HIPPO e seus componentes}

Um equilíbrio coordenado entre proliferação, apoptose e diferenciação celular é essencial para a formação e manutenção de tecidos e órgãos. Estudos recentes indicaram que a efetivação desses processos depende do funcionamento da via do Hipopótamo (HIPPO), uma via de sinalização conservada, crucial para a integração das alterações do citoesqueleto com o ambiente extracelular. A via HIPPO foi identificada em estudos genéticos de Drosophila melanogaster como supressor de crescimento excessivo de tecido (Justice et al., 1995; Jia et al., 2003; Huang et al., 2005).

A ampla importância da via HIPPO na diferenciação e especialização celular é refletida em decorrência da complexa rede de sinais que controlam a atividade de TAZ e YAP e estes por sua vez, tem papéis-chave em coordenar o destino celular, a proliferação e a apoptose. No entanto, estas funções nem sempre são observadas de forma síncrona, podendo 
haver diferença na sua regulação entre espécies. Além disso, os eventos que regulam a via de forma distinta são mal descritos e, portanto, uma melhor compreensão desses mecanismos pode oferecer uma visão importante sobre o desenvolvimento embrionário (Varelas, 2014).

A via HIPPO representa uma cascata de proteínas quinases que regulam a atividade de dois efetores principais, YAP1 (yes-associated 14 protein) e TAZ (transcriptional coactivator with PDZ-binding motif). YAP1 e TAZ se ligam a fatores de transcrição da família TEAD (TEA domain family member; TEAD1, TEAD2, TEAD3 e TEAD4) e regulam a expressão de diversos genes (Zhao et al., 2010; Mauviel et al., 2012). Seus componentes atuam de maneira a formar uma cascata de fosforilações proteicas, que culminam na inibição de YAP e TAZ, que regulam a expressão de genes associados com proliferação e sobrevivência celular (Piccolo et al., 2014).

A via HIPPO geralmente é interpretada como ativa ou inativa. Em sua forma ativa, as quinases MST1 e MST2 fosforilam LATS1 e LATS2 (Callus et al., 2006; Praskova et al., 2008), que por sua vez fosforilam YAP1 e TAZ. Quando YAP1 e TAZ estão fosforiladas, translocam-se para o citoplasma das células, onde ficam retidas ou são degradadas (Zhao et al., 2007; Hao et al., 2008; Zhao et al., 2010). Por outro lado, quando em sua forma inativa, YAP1 e TAZ ficam retidas no núcleo, ligando-se a fatores de transcrição, principalmente da família TEAD, resultando na modulação da atividade transcricional de genes alvo envolvidos com a sobrevivência, proliferação e diferenciação celular (Mauviel et al., 2012).

Estudos têm demonstrado que TAZ ou YAP desempenham papéis importantes em células tronco embrionárias, que são derivadas da MCI do blastocisto e possuem a capacidade de se autorrenovar e dar origem a todos tipos de células funcionais num animal adulto. Eles acabam por controlar os níveis e a ação de um circuito transcricional central que contam com outros genes envolvidos em outros eventos, como OCT4, NANOG e SOX2 (Young, 2011), que são genes associados à pluripotência.

A distribuição nuclear e citoplasmática de YAP define a primeira escolha do destino celular no embrião de camundongos - a diferenciação das células em trofectoderma (TE) ou massa celular interna (MCI) (Cockburn e Rossant, 2010). Um dos primeiros processos a ocorrer no embrião é a compactação, durante o qual há formação das junções de aderência e aquisição de polaridade apical-basal na fase de 8 células (Cockburn e Rossant, 2010). À medida que estas células se dividem, as mais íntimas e mais compactas perdem a sua polaridade, e as suas diferenças em relação às células exteriores resultam numa distribuição díspar de YAP, cujo controle foi demonstrado pela presença de um domínio polar (Korotkevich et al. 2017) ou pela diferença de contratilidade celular (Maître et al. 2016). 
No blastocisto, YAP localiza-se nos núcleos das células externas de mórulas e posteroirmente do TE, mas são distribuídos por todo o citoplasma em células internas e posteriormente da MCI (Nishioka et al., 2009). YAP nuclear controla a atividade do fator de transcrição TEAD4, determinante para a especialização transcricional do TE que inclui a indução do gene $C d x 2$ (Yagi et al., 2007), que é associado à diferenciação do TE (Strumpf et al. 2005). De acordo com isto, a eliminação de Tead4 resulta na perda da expressão de $C d x 2$, gerando embriões que não conseguem estabelecer o TE (Nishioka et al., 2008; Yagi et al., 2007). A eliminação de YAP resulta em células com defeitos de especificação de destino e em morte embrionária na fase de mórula, anterior à especificação de TE ou ICM (Nishioka et al.., 2009).

\subsubsection{Participação do gene LATS no desenvolvimento embrionário}

Nishioka et al. (2009) ainda descreveram o mecanismo biológico pelo qual a via HIPPO controla a translocação nuclear de YAP. TEAD4 ativo pode induzir o Cdx2 e outros genes de trofoblasto em paralelo com células tronco embrionárias. Em embriões, a proteína coativadora de TEAD4, o YAP, localiza-se em núcleos de células externas, e a modulação de atividade de TEAD4 ou YAP leva a mudanças na expressão de Cdx2. Nas células internas, o YAP é fosforilado no citoplasma, e isso envolve a sinalização da via HIPPO e a proteína quinase LATS1/2. No embrião, YAP localiza-se em núcleos somente em células externas e é impossibilitado de se translocar para o núcleo celular de células internas pelo componente LATS1/2 da via de sinalização HIPPO. Essas observações sugerem que o TEAD4/YAP interpreta informações ao longo do eixo interno/externo do embrião para restringir a expressão de Cdx2 e TE para células externas. No embrião de camundongo, TEAD1/TEAD2 mutantes morrem logo após a implantação devido a redução da proliferação celular e aumento do apoptose (Sawada et al., 2008). TEAD1/2 interage geneticamente com YAP (Sawada et al., 2008), sugerindo que os papéis desses genes na via HIPPO são conservados em camundongos.

A supressão de LATS1/2 causa um aumento da localização nuclear de YAP, levando a uma expressão de Cdx2 amplificada, que impede a especificação adequada da MCI (Nishioka et al., 2009; Lorthongpanich et al., 2013). A deleção somente de LATS2 foi capaz de inibir a fosforilação de YAP em embriões murinos (Nishioka et al. 2009). Alguns reguladores da atividade de LATS, como a Mobla e Moblb, quando nocauteados também levam à defeitos de desenvolvimento, com parada no desenvolvimento de embriões em torno do dia 6,5 anterior a gastrulação (Nishio et al., 2012). 


\subsubsection{Via HIPPO em bovinos}

Diferentemente de camundongos, que expressam CDX2 em mórulas, o embrião bovino expressa CDX2 apenas no estágio de blastocisto (Goissis e Cibelli, 2014). Entretanto, YAP localiza-se no núcleo de células do TE, juntamente com CDX2 (Tribulo et al., 2017) Os resultados ainda sugerem que YAP está envolvida na expressão de CDX2 e na diferenciação do TE, mas estudos funcionais são necessários para determinar se o YAP é ou não necessária para a expressão de CDX2 em embriões bovinos. Recentemente, foi demonstrado que TEAD4, cuja atividade é regulada pelo seu co-fator YAP, não é necessário para expressão de CDX2 ou formação do blastocisto bovino (Sakurai et al., 2017). Sharma \& Madan (2019) confirmam a presença de constituintes da via de sinalização de HIPPO, como TAZ e YAP no embrião bovino nos primeiros estágios de desenvolvimento. Contudo, devido a presença concomitante de YAP e CDX2 no TE bovino, é plausível que a via HIPPO possa participar na diferenciação celular bovina, com YAP participando como co-fator de transcrição para outras proteínas regulatórias. 


\subsection{HIPÓTESE}

A deleção de LATS2 resulta em um desenvolvimento sem MCI, em decorrência da inativação da fosforilação de YAP.

Figura 2 - Modelo hipotético gráfico.

Com atividade de LATS2

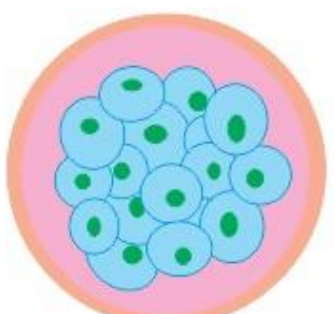

Mórula

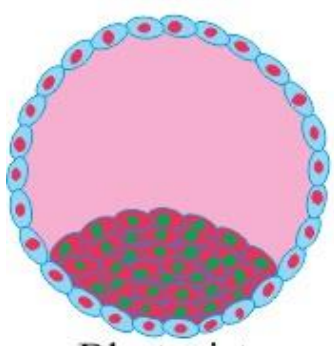

Blastocisto
Após deleção de LATS2

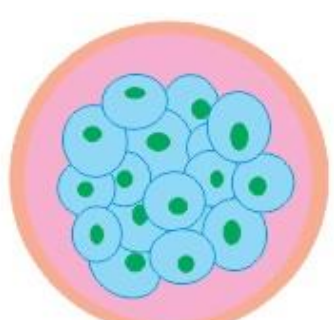

Mórula

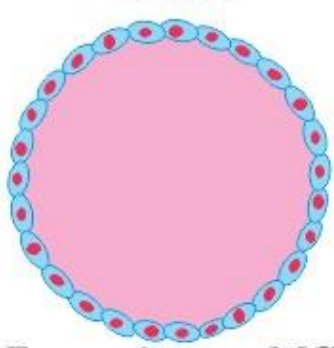

Formação sem MCI

\section{Presença de YAP}

Legenda: à esquerda, estágio de mórula e blastocisto com a atividade de LATS2. À direita, estágio de mórula e formação sem MCI após a deleção de LATS2. Acredita-se que deleção de LATS2 inibirá a via HIPPO, promovendo a exclusiva localização nuclear de YAP e consequentemente impedindo a diferenciação celular da massa interna. 


\subsection{OBJETIVOS}

A similaridade observada na regulação transcricional do desenvolvimento embrionário precoce entre bovinos e humanos, combinado com técnicas de edição genética altamente eficientes tornam o bovino um modelo valioso para a biologia do embrião humano, com aplicações expandidas na agricultura e tecnologias de reprodução assistida (Daigneault et al., 2018). Neste trabalho, objetivamos, portanto:

1 - Inativar a ação quinase da enzima com a deleção gênica de LATS2 via sistema CRISPR/Cas9 (Figura 3);

2 - Compreender a função gênica de LATS2 e consequentemente como a via HIPPO participa na segregação entre MCI e o TE em bovinos

Desta maneira, o trabalho poderá contribuir com o entendimento da diferenciação das células durante o desenvolvimento embrionário inicial.

Figura 3 - Esquema ilustrativo de edição gênica para inativação do domínio quinase de LATS2.

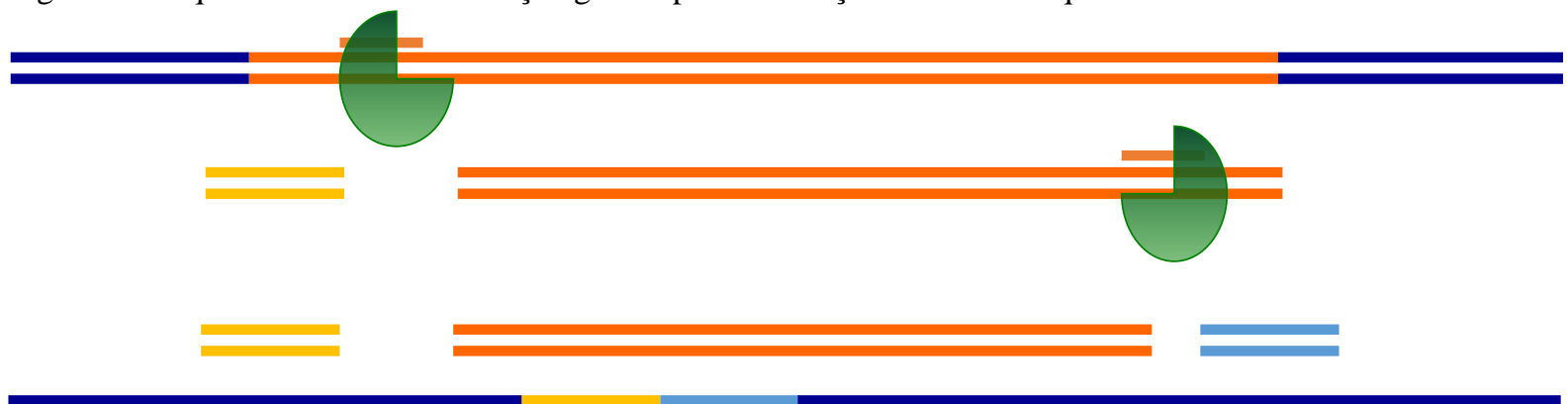

Legenda: A dupla fita de DNA está representada na figura. As diferentes cores indicam diferentes trechos de DNA. O domínio de proteína quinase de LATS2 está representado em laranja. A região 5' após o corte pela enzima CAS9 (em verde) guiada pelo gRNA1 está representada em amarelo. A região 3' após o corte pela enzima CAS9 (em verde) guiada pelo gRNA2 está representada em azul claro. O corte da sequência via sistema CRISPR/Cas9 inativa o domínio quinase da enzima, inviabilizando a fosforilação de YAP e consequentemente, interferindo diretamente sobre o processo de diferenciação e especialização celular nos estágios iniciais do desenvolvimento embrionário (imagem cedida por Marcelo Demarchi Goissis). 


\subsection{MATERIAL E MÉTODOS}

O presente estudo foi realizado conforme os princípios éticos de experimentação animal estabelecidos pela Comissão de Ética no Uso de Animais (CEUA) da Faculdade de Medicina Veterinária e Zootecnia da Universidade de São Paulo - FMVZ - USP (protocolo número: 7341170818). Os materiais foram comprados da Merck-Sigma-Aldrich, a menos que indicado de outra maneira.

3.4.1 Local do experimento e período de execução

$\mathrm{O}$ experimento foi realizado no laboratório de Fecundação in vitro, Clonagem e Transgenia Animal, localizado no departamento de Reprodução Animal da Faculdade de Medicina Veterinária e Zootecnia da Universidade de São Paulo, campus da Capital.

\subsubsection{Delineamento experimental}

Para a deleção gênica de LATS2 em embriões bovinos, foi utilizado o sistema CRISPR/Cas9, microinjetado em zigotos produzidos in vitro. Embriões bovinos foram produzidos in vitro conforme descrito (Goissis e Cibelli, 2014). Os zigotos foram microinjetados com gRNA para LATS acompanhado de cRNA para Cas9. Zigotos não microinjetados e microinjeção com Cas9 apenas foram utilizados como controles. Os embriões foram cultivados in vitro até o dia 8 após a fertilização. No dia 8 foram avaliadas taxas de formação de blastocistos, o número de células e sua distribuição quanto a MCI e TE, além da fixação das estruturas em formaldeído 3,8\%. Aproximadamente 3 embriões por replicata foram genotipados por PCR para verificação da deleção dos genes. Imunofluorescência para verificar expressão proteica de YAP foi realizada em com 3 embriões em dia 8 de cultivo.

\subsubsection{Construções moleculares}

A formulação de toda a maquinaria CRISPR/Cas9 conta com processos in silico a partir da sequência específica do determinado gene a ser editado. O software online CRISPR RGEN Tools (disponível para acesso via site: http://www.rgenome.net/cas-designer/) foi usado para desenho das sequências de RNA guia (gRNA1 e gRNA2) alvejando a região codificadora correspondente ao domínio de proteína quinase do gene LATS2, (Gen Bank accession number XM_025000092.1), com auxílio do software online blastx (disponível em https://blast.ncbi.nlm.nih.gov/Blast.cgi). As sequências de oligonucleotídeos Forward (5', 
para 3') e Reverse (3' para 5') são complementares e foram sintetizadas comercialmente e estão inseridas na tabela 1 .

Tabela 1. Sequências de oligonucleotídeos utilizadas neste estudo.

\begin{tabular}{|c|c|c|}
\hline & Forward $\left(5^{\prime}-3^{\prime}\right)$ & Reverse (5' - 3') \\
\hline gRNA1 & caccGAAGGTGAAGACCCTGGGCGT & aaacACGCCCAGGGTCTTCACCTTC \\
\hline gRNA2 & caccGGCGGAGGCGGACAATGAAT & aаacATTCATTGTCCGCCTCCGCC \\
\hline gRNA1 IVT & $\begin{array}{c}\text { TAATACGACTCACTATAGGGAAGGTGA } \\
\text { AGACCCTGGGCGT }\end{array}$ & AAAAGCACCGACTCGGTGCC \\
\hline gRNA2 IVT & $\begin{array}{c}\text { TAATACGACTCACTATAGGGGCGGAGG } \\
\text { CGGACAATGAAT }\end{array}$ & AAAAGCACCGACTCGGTGCC \\
\hline $\begin{array}{l}\text { LATS2 } \\
\text { genotipagem }\end{array}$ & GTTCTGCACCCTCCTTTCCAC & CTATGAGGATGTTGTCGGGCT \\
\hline
\end{tabular}

Legenda: letras minúsculas indicam sequência adaptadora necessária para clonagem em plasmídeo pX330-Cas9. Letras em verde indicam sequência adaptadora para transcrição in vitro (IVT).

\subsubsection{Síntese de gRNAs}

Após a produção dos guias de RNA para o gene LATS, foram realizados 6 principais procedimentos, que consistem no anelamento das fitas $F$ e $R$, abertura do plasmídeo por digestão com enzima de restrição, adição de fosfato aos primers anelados, eletroforese com o plasmídeo que foi digerido e posterior extração do DNA contido no gel, inserção dos primers fosforilados dentro do plasmídeo purificado e por fim, a inserção desse material nas bactérias competentes, seguido pelo crescimento das colônias. Após o crescimento de colônias resistentes ao antibiótico do meio, é feita a extração do DNA plasmidial com auxílio de um kit, quantificação e sequenciamento. Essas etapas serão detalhadas adiante.

\subsubsection{Anelamento e fosforilação}

$\mathrm{O}$ anelamento das fitas simples foi feito por adição dos oligonucleotídeos $(F$ e $R)$, água ultra pura e tampão CutSmart (New England Biolabs, Ipswich, MA, EUA) a um tubo de PCR e submetido ao programa de anelamento em termociclador $\left(95^{\circ} \mathrm{C}-10\right.$ min.; $95^{\circ} \mathrm{C}$ para $85^{\circ} \mathrm{C}$ em - $2^{\circ} \mathrm{C} /$ seg.; $85^{\circ} \mathrm{C}-1$ min.; $85^{\circ} \mathrm{C}$ para $75^{\circ} \mathrm{C} \mathrm{em}-3^{\circ} \mathrm{C} /$ seg.; $75^{\circ} \mathrm{C}-1$ min.; $75^{\circ} \mathrm{C}$ para $65^{\circ} \mathrm{C}-$ $3^{\circ} \mathrm{C} /$ seg.; $65^{\circ} \mathrm{C}-1$ min.; $65^{\circ} \mathrm{C}$ para $55^{\circ} \mathrm{C}-3^{\circ} \mathrm{C} /$ seg.; $55^{\circ} \mathrm{C}-1$ min.; $55^{\circ} \mathrm{C}$ para $45^{\circ} \mathrm{C}-3^{\circ} \mathrm{C} /$ seg.; $45^{\circ} \mathrm{C}-1$ min.; $45^{\circ} \mathrm{C}$ para $35^{\circ} \mathrm{C}-3^{\circ} \mathrm{C} /$ seg.; $35^{\circ} \mathrm{C}-1$ min.; $35^{\circ} \mathrm{C}$ para $25^{\circ} \mathrm{C}-3^{\circ} \mathrm{C} / \mathrm{seg}$.; $25^{\circ} \mathrm{C}-1$ min.; $4^{\circ} \mathrm{C}$ indefinidamente). $\mathrm{O}$ produto anelado foi então submetido à reação de fosforilação 
na qual são adicionados a um tubo de PCR: o oligonucleotídeo anelado, enzima T4 PNK (New England Biolabs), ATP, e tampão 10X PNK buffer; seguido de incubação no termociclador à $37^{\circ} \mathrm{C}$ por 30 minutos seguido de inativação à $75^{\circ} \mathrm{C}$ por 10 minutos. $\mathrm{Na}$ sequência, realiza-se a etapa de clonagem do protocolo de CRISPR.

3.4.3.3 Clonagem: digestão plasmidial, purificação, ligação e transformação bacteriana Inicialmente, foi realizada a clonagem em vetor pX330-U6-Chimeric_BB-CBhhSpCas9 (pX330-Cas9, Cong et al., 2013; Addgene, Watertown, MA, EUA). O plasmídeo pX330-Cas9 foi submetido à digestão com a endonuclease BbsI. A digestão de $5 \mu \mathrm{g}$ de plasmídeo ocorreu a $37^{\circ} \mathrm{C}$ em banho seco, durante $3 \mathrm{~h}$. O material oriundo da digestão foi submetido à eletroforese em gel de agarose e após a leitura e confirmação da presença de banda linear, foi purificado com kit (Pure Link, Quick gel extraction, Thermo Fisher, Waltham, MA, EUA. Após a purificação, realizou-se a quantificação do material genético na amostra com uso de espectrofotômetro Nanodrop. A ligação entre o vetor pX330-Cas9 e o oligonucleotídeo fosforilado foi realizado com a enzima T4 DNA Ligase, Buffer 10X T4 DNA (Takara Bio Inc, Shiga, Japão). A ligação ocorreu em $16^{\circ} \mathrm{C}$ durante $12-16 \mathrm{~h}$. A ligação foi então usada para a transformação de bactérias competentes. As bactérias armazenadas em um tubo tipo Eppendorf 1,5 $\mathrm{ml}$ foram colocadas em gelo durante 5 minutos e após, foram adicionados $2 \mu \mathrm{g}$ do material do processo de ligação ao tubo e deixando novamente em gelo, por mais 20 minutos. Após esse período, realizou-se o choque térmico em banho seco a $42^{\circ} \mathrm{C}$ durante 90 segundos e em seguida, o tubo foi inserido no gelo novamente por mais 5 minutos. Ressuspendeu-se o material do tubo em $100 \mu \mathrm{g}$ de meio LB e então a amostra foi plaqueada em LB Agar com $100 \mu / \mathrm{ml}$ de ampicilina e colocada em estufa a $37^{\circ} \mathrm{C}$ por $12-16 \mathrm{~h}$ para crescimento das bactérias transformadas com o plasmídeo requerido. Após o crescimento de colônias, algumas delas foram selecionadas para cultivo em meio líquido e posterior extração do DNA plasmidial.

\subsubsection{Extração do DNA plasmidial}

Após cultivo em meio líquido, realizou-se a extração do DNA plasmidial e posterior quantificação com uso de espectrofotômetro Nanodrop. A extração foi realizada com o kit Quick Plasmid Miniprep Invitrogen, by Thermo Fisher Scientific. Após a mensuração da quantidade do material extraído, foi realizado PCR com um oligonucleotídeo homólogo a região promotora U6 do px330 e com os primers reverse dos gRNA (tabela 1). A PCR foi realizada com $300 \mu \mathrm{g}$ de plasmídeo com programa de $94^{\circ} \mathrm{C} 1 \mathrm{~min}, 35 / 40$ ciclos $94^{\circ} \mathrm{C} 30 \mathrm{~s}$, 
$60^{\circ} \mathrm{C} 30 \mathrm{~s}, 72^{\circ} \mathrm{C} 60 \mathrm{~s}$, seguido de $72^{\circ} \mathrm{C}$ por 2 min com enzima Taq polimerase (Cellco, São Carlos, Brasil). O produto esperado era de 226 pares de base (figura 4). As amostras plasmidiais contendo o gRNA 1 e gRNA 2 para o gene LATS2 foram enviadas para sequenciamento pelo método Sanger, no Instituto de Biociências da USP. Os resultados obtidos no sequenciamento das amostras demonstraram uma correta inserção dos RNA guias.

Figura 4 - Confirmação de clonagem de sequência de gRNA no plasmídeo pX330 por PCR.

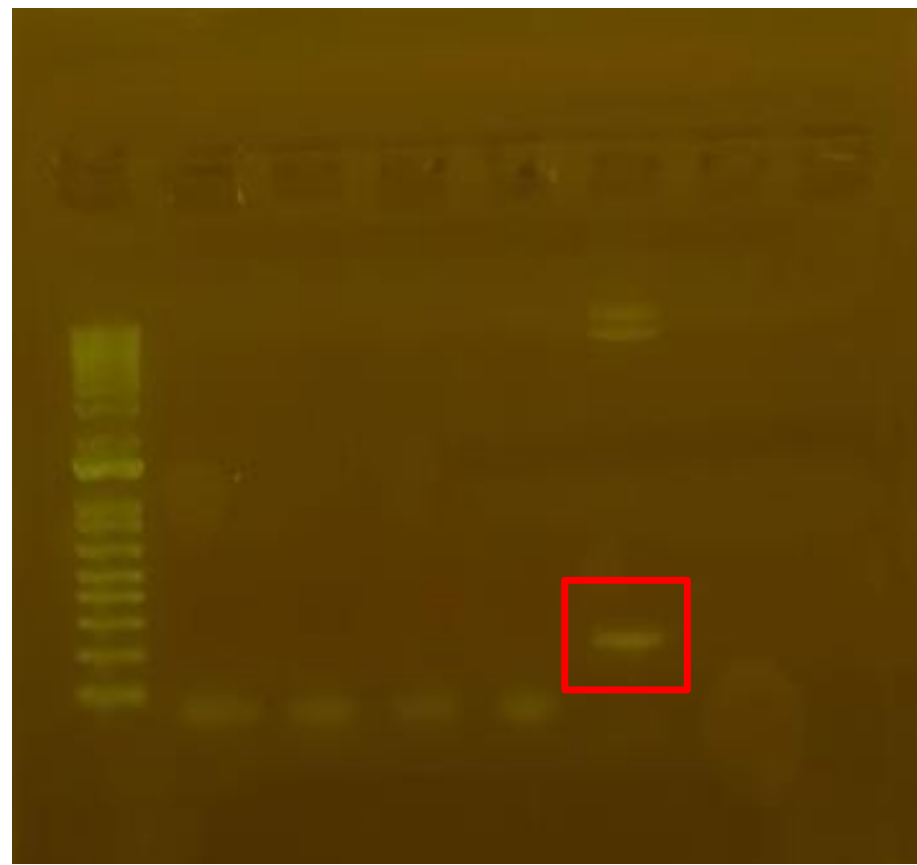

Legenda: eletroforese de DNA plasmidial evidenciando, no último poço com marcação em vemelho, contendo 226 pares de base, um dos gRNAs guia para LATS2.

3.4.4 Síntese in vitro dos gRNAs

A síntese in vitro dos gRNAs a partir dos vetores gerados foi realizada com kit MEGAshortscript ${ }^{\mathrm{TM}}$ T7 Transcription (ThermoFisher) seguindo instruções do fabricante, após amplificação por PCR da sequência dos gRNA 1 e 2, com adição de sequência promotora T7 (Tabela 1).

\subsubsection{Produção in vitro de embriões bovinos}

Oócitos bovinos foram obtidos de ovários aspirados coletados de matadouros comerciais. Foram selecionados os complexos cumulus-oócito de acordo com sua qualidade e maturados in vitro (MIV) em meio de maturação consistindo de meio TCM-199 suplementado com 10\% de Soro Fetal Bovino, $3 \mu \mathrm{g} / \mathrm{ml}$ de hormônio luteinizante (Vetecor Laboratories, Callier, Spain), $3 \mu \mathrm{g} / \mathrm{ml}$ de hormônio folículo estimulante (Folltropin-V, Vetrepharm, Inc. Belleville, ON, Canada), 1mg/ml estradiol, 22 ug/ml de piruvato de sódio e 
$25 \mathrm{ug} / \mathrm{ml}$ de gentamicina. Após 22h, os oócitos foram submetidos à fertilização in vitro. A fecundação in vitro (FIV) foi realizada em meio de fertilização à base de piruvato de lactato de Tyrode (TALP) suplementado com $20 \mu \mathrm{g} / \mathrm{ml}$ de heparina. Após o descongelamento a $37^{\circ} \mathrm{C}$, foram adicionados os espermatozoides vivos, selecionados pelo gradiente de Percoll@, a gota de meio de fertilização contendo os oócitos em uma concentração de 1 x 106 espermatozoides $/ \mathrm{ml}$. A fertilização ocorreu durante um período de $10 \mathrm{~h}$ a $38,5{ }^{\circ} \mathrm{C}$ e $5 \%$ de $\mathrm{CO} 2$ em alta umidade. Após 10h, realizou-se o cultivo in vitro (CIV), onde os presumíveis zigotos foram expostos a 3 minutos de vórtex para retirada das células do cumulus e lavados em meio de cultura de embrião Hamster-Hepes $(\mathrm{HH})$ antes de serem colocados em microgotas de meio KSOM suplementado com aminoácidos (KSOM + AA), sob óleo. Nesse momento, as estruturas foram microinjetadas ou não - o que será descrito adiante - e após, cultivadas a $38,5^{\circ} \mathrm{C}$ em umidade elevada. No dia 4 de cultivo, foram avaliadas as taxas de clivagem e a troca de 30 ul do meio das gotas por 30 ul de meio KSOM + AA. No dia 8 as taxas Blastocisto (BL) (BL/número de oócitos) foram avaliadas. Os embriões foram então submetidos à imunofluorescência, genotipagem via PCR e sequenciamento. Os embriões obtidos após o retorno das atividades pós-pico da pandemia de COVID-19 foram corados com $10 \mu \mathrm{g} / \mathrm{ml}$ Hoechst por 10 minutos e verificados em microscopia de fluorescência com cerca de 15 segundos de exposição e 5 imagens usando a função Z-stack do software Olympus CellSens Dimension. Os dados foram tabelados, as estruturas foram avaliadas quanto a morfologia e suas respectivas células contadas. Posteriormente, as estruturas foram armazenadas individualmente em solução para extração de RNA e congeladas em $-80^{\circ} \mathrm{C}$.

\subsubsection{Microinjeções em zigotos bovinos}

$\mathrm{Na}$ microinjeção, uma micropipeta de sucção segura o zigoto enquanto uma micropipeta de injeção é alinhada e introduzida medialmente a estrutura. Uma pequena aspiração do conteúdo celular ocorre, a fim de que se verifique a correta inserção da micropipeta e a microinjeção do conteúdo é evidenciada pelo aumento de volume do zigoto.

Os zigotos foram divididos em 3 grupos experimentais sendo: controle (sem microinjeção); Cas9 - microinjetado apenas com Cas9 e LATS gRNA - microinjetado com os gRNAs e Cas9. Os zigotos foram microinjetados com aproximadamente 8pl de solução $12.5 \mathrm{ng} / \mu \mathrm{l}$ de cada gRNA acompanhado de $70 \mathrm{ng} / \mu \mathrm{l}$ de proteína CAS9. Zigotos não

microinjetados e microinjeção com CAS9 apenas foram utilizados como controles. Foram realizadas 3 replicatas válidas antes da paralisação das atividades devido à COVID-19. 


\subsubsection{Microinjeções em oócitos maduros (MII)}

Devido às restrições de acesso ao campus no período do pico da pandemia de COVID19 , as injeções às $10 \mathrm{~h}$ pós-FIV ficaram impossibilitadas. Como alternativa, foram realizadas injeções em oócitos supostamente em metáfase II, 22h após início da MIV. Os oócitos foram parcialmente denudados em solução de $1 \mathrm{mg} / \mathrm{ml}$ de hialuronidase em meio $\mathrm{HH}$ por 3 minutos no vórtex. Os oócitos foram injetados como descrito acima com os mesmos grupos experimentais. O grupo controle não injetado também foi submetido à denudação. A FIV foi então realizada após as injeções como descrito acima. O CIV foi modificado apenas para exclusão do vórtex e remoção das células do cumulus restantes por pipetagem. Os blastocistos obtidos no dia 8 de cultivo foram avaliados e colhidos como descrito acima para os embriões no período pós-restrição.

\subsubsection{Imunofluorescência para YAP}

As estruturas no D8 foram então fixadas em formaldeído. O protocolo padrão consistiu em fixação dos embriões em solução 3,8\% formaldeído (Sigma-Aldrich) em PBS suplementado com $1 \mathrm{mg} / \mathrm{ml}$ polivinilpirrolidona (PBS-PVP) por 15 minutos. Os embriões foram lavados por três vezes e armazenados a $4^{\circ} \mathrm{C}$ em PBS-PVP até o processamento. $\mathrm{O}$ protocolo da técnica de imunofluorescência para verificar expressão proteica de YAP consistiu na lavagem dos embriões fixados em solução de lavagem (PBS + 0,1\% Triton X100) e permeabilização em solução de PBS com $0,5 \%$ Triton $X-100$ por 15 minutos à temperatura ambiente. Os embriões foram novamente lavados e incubados por $1 \mathrm{~h}$ à temperatura ambiente em solução de bloqueio (solução de lavagem suplementada com 10\% soro de jumento e $1 \% \mathrm{BSA}$ ). Na sequência foram incubados com anticorpo primário de coelho anti-YAP (ab52771, Abcam) diluído 1:62,5 em solução para anticorpo (solução de lavagem suplementado com $1 \%$ BSA). As condições de incubação dos anticorpos primários foi a $4^{\circ} \mathrm{C}$ de 16 a $20 \mathrm{~h}$. Os embriões foram lavados três vezes por 10 minutos à temperatura ambiente e incubados com anticorpo secundário por 1h à temperatura ambiente. Os embriões foram lavados três vezes por 10 minutos à temperatura ambiente e incubados com $100 \mu \mathrm{g} / \mathrm{ml}$ Hoechst 33342 por 10 minutos a temperatura ambiente. Na sequência foram lavados três vezes em PBS-PVP antes da montagem das lâminas. Os embriões foram montados entre lamínulas, com auxílio de adesivo espaçador de $0,12 \mathrm{~mm}$ de altura e observados em microscópio confocal Olympus Fluo View 1000 (Olympus Corporation, Tokyo, Japan) no Centro Avançado de Diagnóstico por Imagem, Faculdade de Medicina Veterinária e Ciência Animal, Universidade de São Paulo. A excitação do fluoróforo foi induzida pelo laser diodo 
405nm, laser de argônio 488nm e laser de neon-helium 546nm. Foram obtidas imagens a cada $8 \mu \mathrm{m}$, utilizando o software CellSens Dimension (Olympus).

\subsubsection{Genotipagem}

A extração de DNA dos embriões após a realização da imunofluorescência foi realizada via kit Extract-N-Amp, com modificações. De modo breve, as reações foram

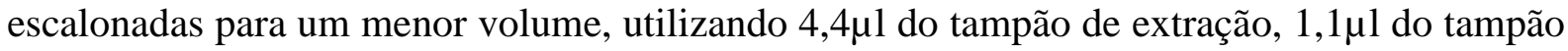
de preparo de tecido e $4,4 \mu 1$ do tampão de neutralização, seguindo os tempos recomendados pelo fabricante. Um total de 3 embriões do grupo gRNA e um embrião de cada grupo controle ou Cas9 foram genotipados por PCR para verificação da deleção de região do gene LATS2. Os produtos foram verificados por eletroforese em gel de agarose. As bandas foram excisadas do gel, purificadas com kit QIAquick PCR \& Gel Cleanup Kit (Qiagen) e submetidas à sequenciamento Sanger no Instituto de Biociências da USP. As sequências foram alinhadas usando software online gratuito de alinhamento múltiplo T-coffee (https://www.ebi.ac.uk/Tools/msa/tcoffee/, Madeira et al. 2019). 


\section{RESULTADOS}

4.1 Avaliações durante o cultivo embrionário - Primeira fase de manipulações

Inicialmente foram realizadas 3 replicatas, antes da restrição devido à pandemia de COVID-19. Os dados de número de zigotos, taxas de clivagem (clivados/oócitos), formação de blastocisto (blastocistos/oócitos) e desenvolvimento (blastocistos/clivados) das 3 replicatas realizadas nesse período estão descritos na tabela 2 e sumarizados no gráfico 1.

Não houve análise estatística devido à falta de graus de liberdade para realizar a ANOVA com comparação de médias. Em uma das replicatas da primeira fase de manipulações, observou-se que os embriões do grupo gRNA - microinjetados com os RNAs guia para o gene LATS2 acrescidos da proteína Cas9 — , apesar de não formarem muitos blastocistos, tinham estruturas assemelhadas a mórulas, que pode ser melhor observado após coloração com $10 \mu \mathrm{g} / \mathrm{ml}$ Hoechst (Figura 6). Foi possível observar que alguns embriões ultrapassaram o estágio de 16 células, mas não formaram blastocistos.

Não foi possível realizar a análise estatística com os dados da primeira fase de manipulação. Contudo, as médias dos dados das 3 replicatas realizadas bem como seus respectivos erros padrão foram inseridos no gráfico 1 . Nota-se que as médias de taxa de formação de blastocisto e desenvolvimento no grupo gRNA são bastantes discrepantes quando comparadas as dos demais grupos. Após as análises das taxas citadas, as estruturas foram fixadas em formaldeído 3,8\% e armazenados em solução de PBS/PVP.

Tabela 2 - Taxas de clivagem, formação de blastocistos e desenvolvimento das 3 primeiras replicatas.

\begin{tabular}{|c|c|c|c|c|c|c|}
\hline \multirow[t]{2}{*}{ Grupo } & \multirow[t]{2}{*}{ Data } & \multirow[t]{2}{*}{ Replicata } & \multirow[t]{2}{*}{ Zigotos } & Clivagem & Blastocistos & Desenvolvimento \\
\hline & & & & \multicolumn{3}{|c|}{ Taxas (\%) } \\
\hline Controle & $20 / 02 / 2020$ & $1^{\mathrm{a}}$ & 60 & 53 & 33 & 63 \\
\hline Controle & $29 / 02 / 2020$ & $2^{\mathrm{a}}$ & 60 & 55 & 27 & 48 \\
\hline Controle & $13 / 03 / 2020$ & $4^{\mathrm{a}}$ & 38 & 66 & 29 & 44 \\
\hline Cas 9 & $20 / 02 / 2020$ & $1^{\mathrm{a}}$ & 17 & 29 & 24 & 80 \\
\hline Cas 9 & $29 / 02 / 2020$ & $2^{\mathrm{a}}$ & 16 & 31 & 0 & - \\
\hline Cas 9 & $13 / 03 / 2020$ & $4^{\mathrm{a}}$ & 30 & 47 & 7 & 14 \\
\hline gRNA Lats & $20 / 02 / 2020$ & $1^{\mathrm{a}}$ & 28 & 54 & 4 & 7 \\
\hline gRNA Lats & $29 / 02 / 2020$ & $2^{\mathrm{a}}$ & 33 & 36 & 6 & 17 \\
\hline gRNA Lats & $13 / 03 / 2020$ & $4^{a}$ & 27 & 59 & 7 & 13 \\
\hline
\end{tabular}


Figura 5 - Imagens de embriões dos três grupos experimentais no D8 de cultivo in vitro.
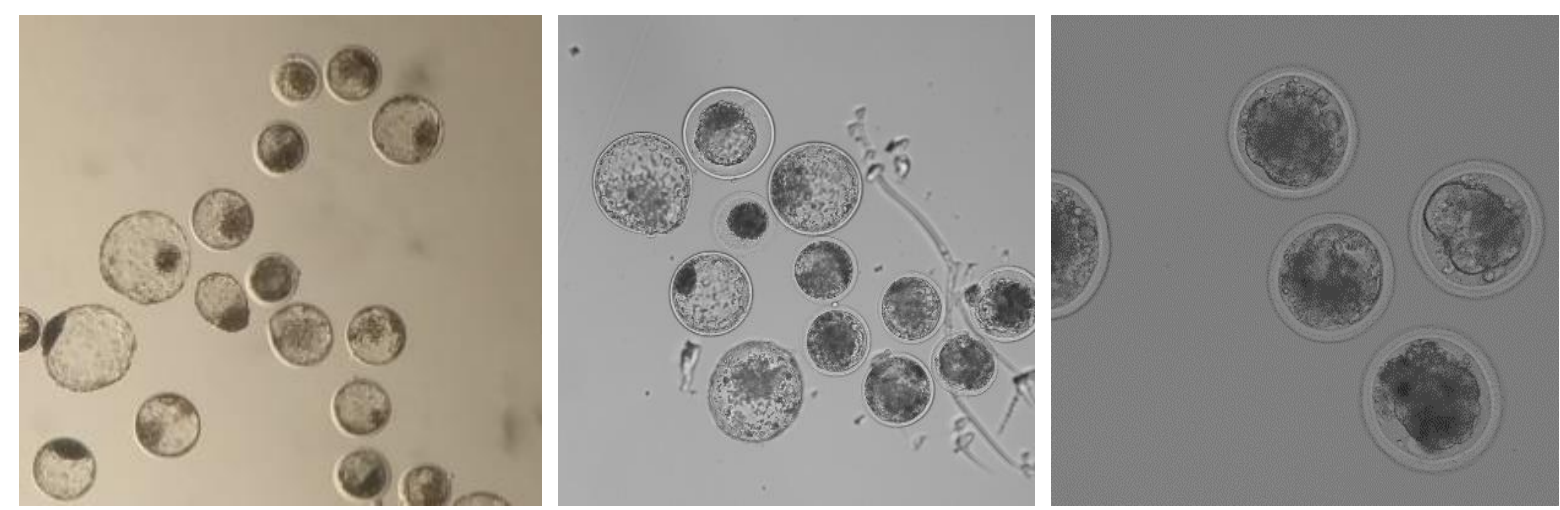

Legenda: A: grupo controle; B: grupo microinjetado apenas com Cas9; C: grupo microinjetado com gRNA para LATS2 e Cas9.

Figura 6 - Embriões injetados com LATS2 gRNA corados com 10 $\mu \mathrm{g} / \mathrm{ml}$ Hoechst 33342 (Sigma) após 8 dias de cultivo in vitro (aumento 200x).

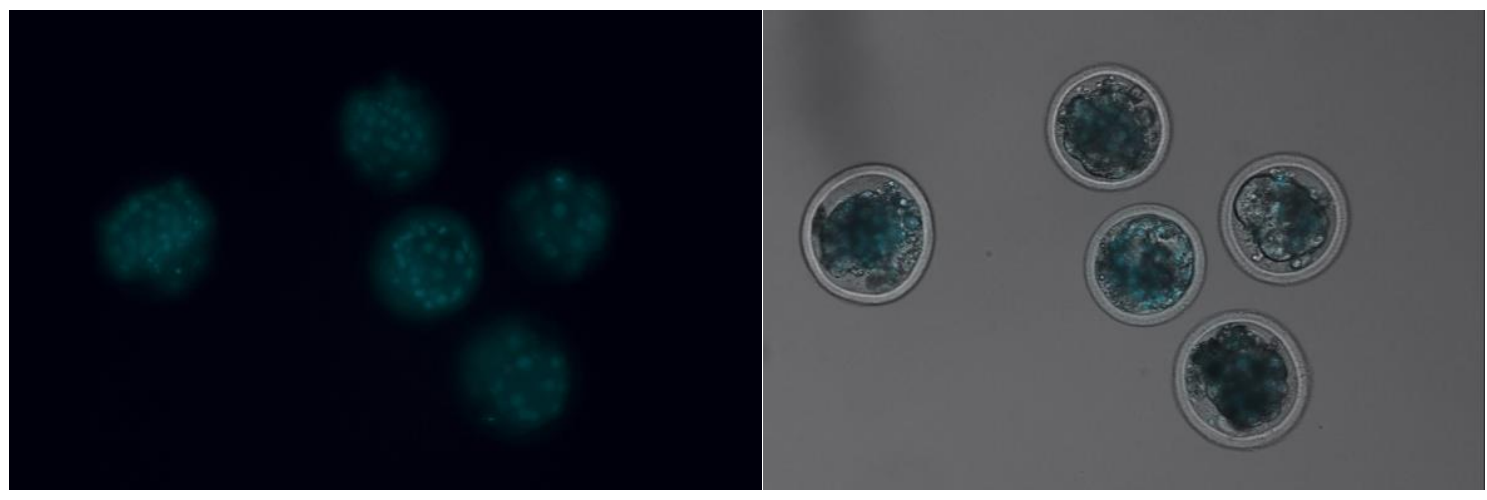

Gráfico 1 - Média das taxas de clivagem, blastocisto e desenvolvimento das primeiras 3 replicatas

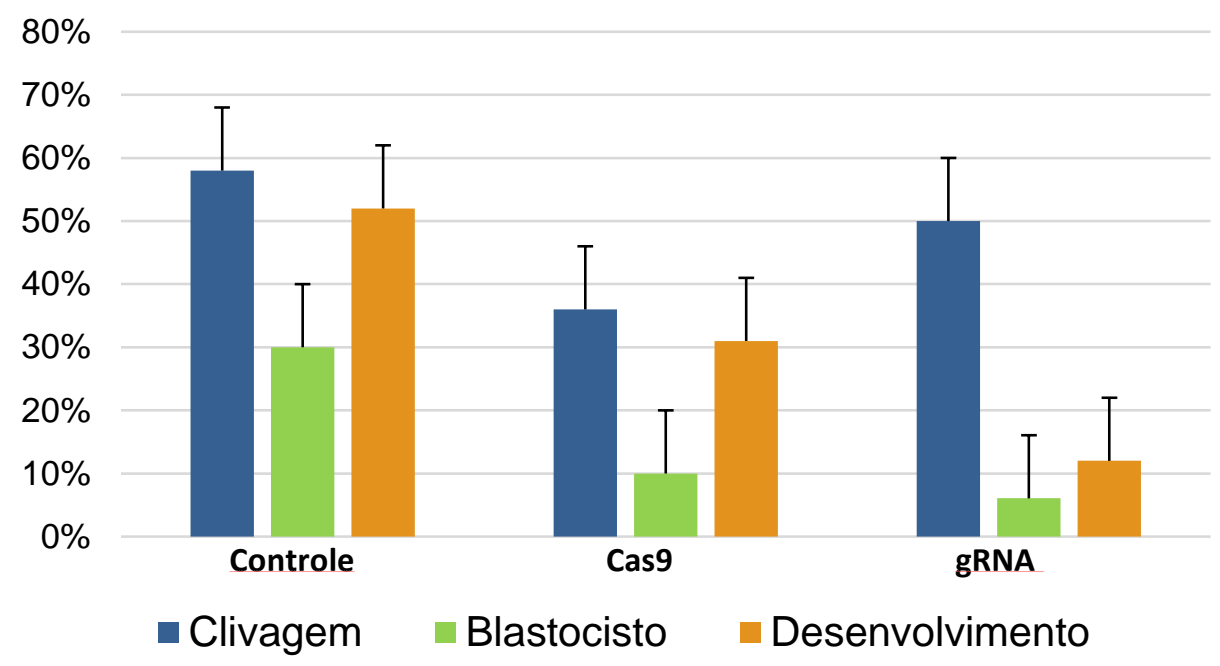

Legenda: azul - taxa de clivagem (embriões clivados/estruturas cultivadas); verde - taxa de blastocisto (blastocistos/estruturas cultivadas); amarelo - taxa de desenvolvimento (blastocistos/embriões clivados). As barras de erro representam o erro padrão da média. 


\subsection{Detecção de YAP}

A técnica de imunofluorescência foi realizada para a proteína YAP, conforme protocolo descrito em Material e Métodos. YAP foi detectado no núcleo de células do trofectoderma e no citoplasma de células da massa celular interna, em embriões não editados, entretanto o mesmo padrão não foi observado. As imagens obtidas através da microscopia confocal das estruturas dos 3 grupos experimentais estão inseridas na figura 7. Os embriões do grupo injetado com gRNA foram denominados gRNAe1, gRNAe2 e gRNAe3

\subsection{Genotipagem}

Após a imunofluorescência, os embriões passaram pelo processo de extração de DNA e posterior PCR. A eletroforese das amostras deveria evidenciar 649 pares de base para a banda de LATS2 intacta. Na amostra de uma das estruturas do grupo gRNA (amostra gRNA e2 da imunofluorescência) houve a presença da banda esperada de 478 pares de base após a edição, sugerindo a perda de cerca de 172 pares de base (figura 8). 
Figura 7 - Imunofluorescência para YAP em microscopia confocal.

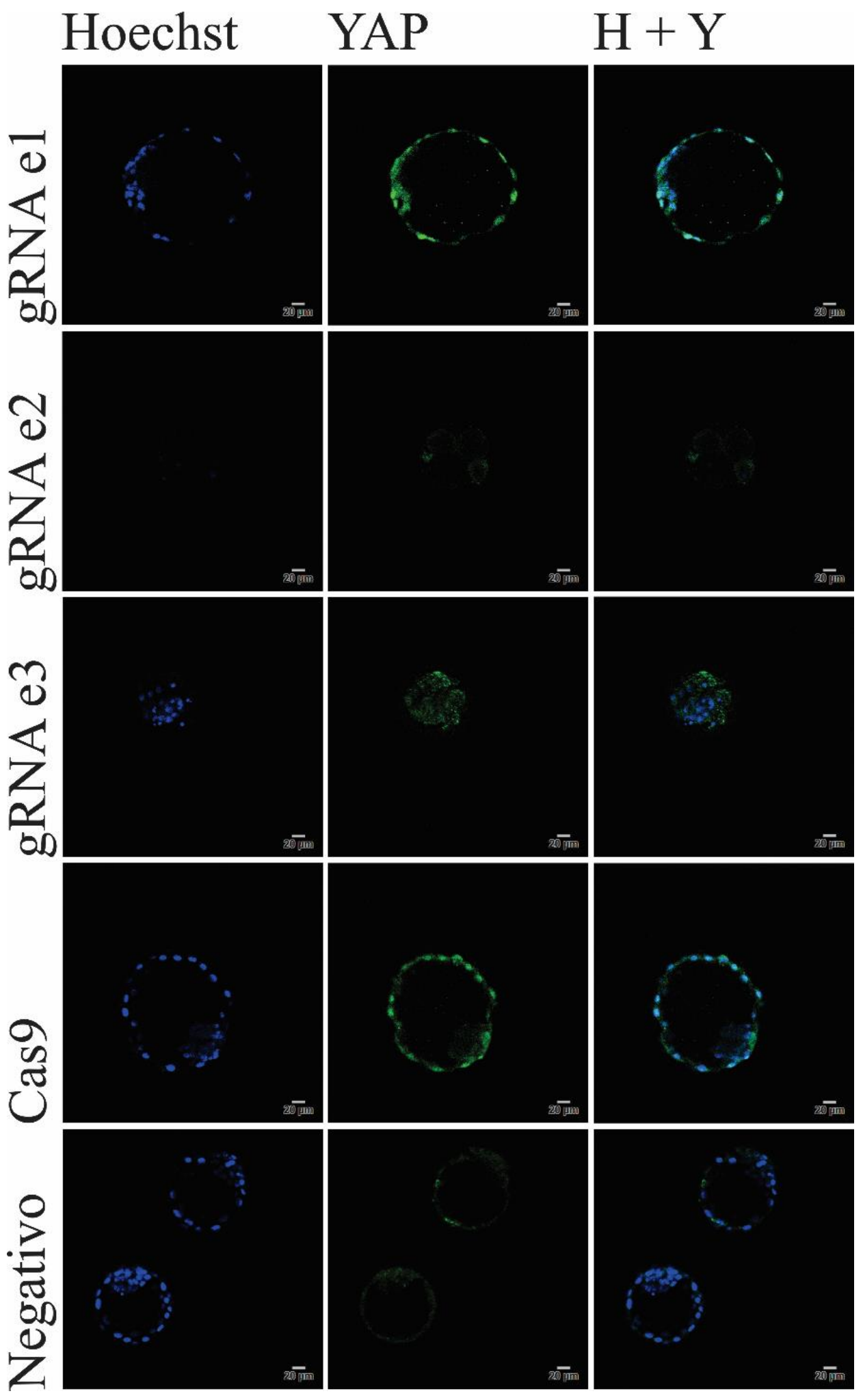

Legenda: Coloração em Hoechst marcando os núcleos celulares e YAP marcando o citoplasma de células da MCI e o núcleo de células do TE. Imagens gRNA e1, e2 e e3 referem-se a estruturas do grupo gRNA, sendo a primeira delas - gRNA e1 - um blastocisto cujo genoma não foi editado; gRNAe2 e e3 são estruturas semelhantes a mórulas quanto a sua morfologia e cuja edição foi confirmada por sequenciamento. Demais imagens para o grupo Cas9, demonstrando coloração normal para um embrião não editado e embrião negativo, demonstrando a funcionalidade do anticorpo utilizado. 
Figura 8 - Resultado de genotipagem da região gênica de LATS2 por PCR

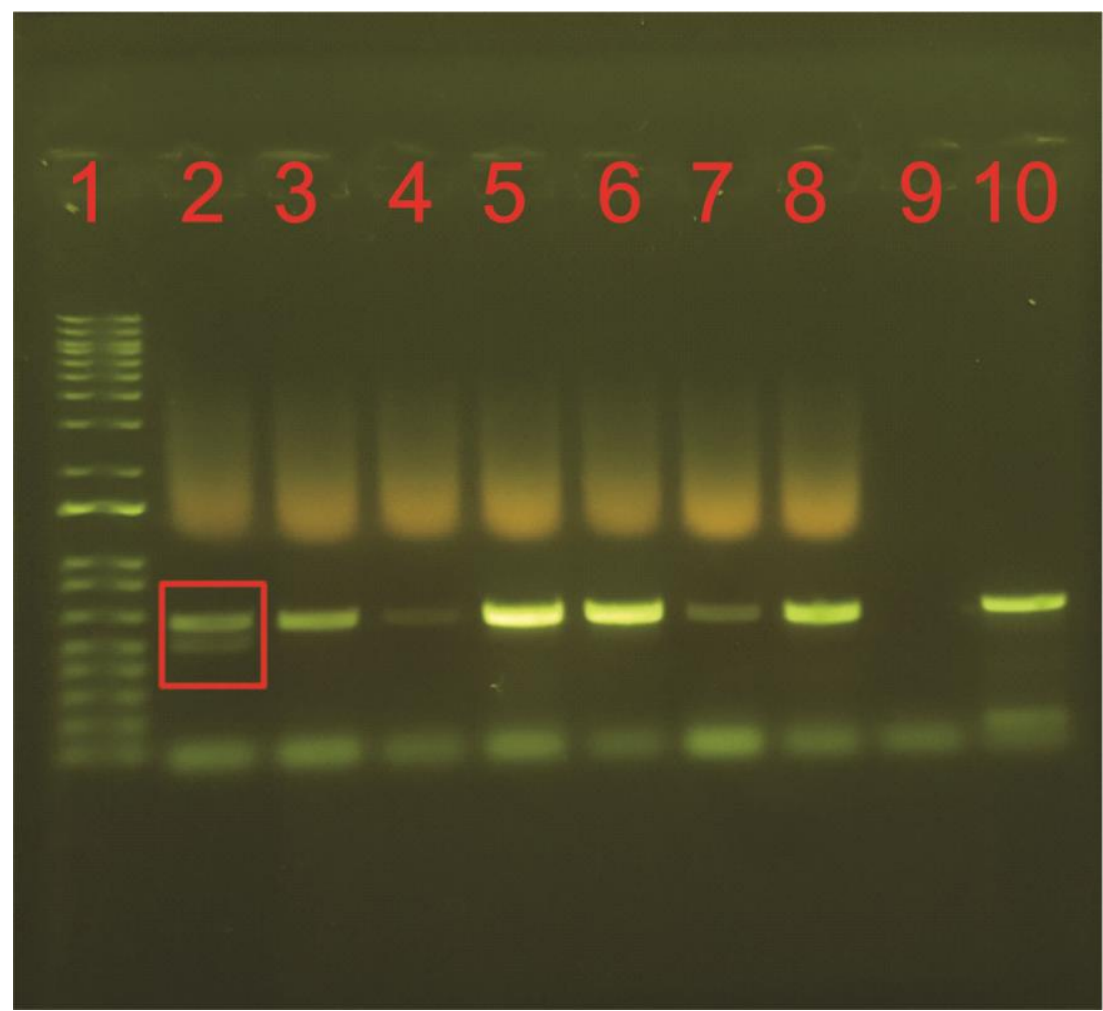

Legenda: Produtos da PCR visualizados por separação eletroforética em gel de agarose. Poço 1 - marcador de peso molecular; poço 2 - amostra do grupo gRNA, nomeada como gRNAe2 nas imagens de imunofluorescência, evidenciada pelo retângulo vermelho onde nota-se a presença de uma banda de $477 \mathrm{pb}$, sugestivo de alteração gênica nesse embrião; poço 3 - amostra do grupo gRNA, nomeada como gRNAe nas imagens de imunofluorescência; poço 4 - amostra do grupo gRNA; poços 5 e 6 - amostras do grupo Cas; poços 7 e 8 amostras do grupo controle; poço 9 - amostra negativa com h2O; poço 10 - amostra controle com DNA de fibroblasto bovino.

\subsection{Sequenciamento pelo método Sanger}

Após a eletroforese, as amostras de embriões dos 3 grupos experimentais passaram pelo processo de sequenciamento através do método Sanger. Análise do sequenciamento demonstrou diversas alterações na sequência genética do embrião gRNAe2, além de revelar deleção de 4 pares de base na sequência genética do embrião gRNAe3 na região alvo do gene LATS2 (figura 9). As sequências foram alinhadas usando software online gratuito de alinhamento múltiplo T-coffee (https://www.ebi.ac.uk/Tools/msa/tcoffee/, Madeira et al. 2019). 
Figura 9 - Alinhamento das sequências dos produtos de genotipagem por PCR

Cas 9

Control

Exon_4_LATS2

LATS2 gRNA_1

* LATS2_gRNA_2_477bp_band

LATS2_gRNA_2_649bp_band

LATS2_gRNA_3

Cas 9

Control

EXon_4_LATS2

LATS 2 - gRNA_1

* LATS2_gRNA_2_477bp_band

LATS2 gRNA 2 649bp band

LATS2_gRNA_3

Cas 9

Control

Exon 4 LATS2

LATS 2 - gRNA_1

* LATS2_gRNA 2 477bp band

LATS2_gRNA_2_649bp_band

LATS2_gRNA_3

Cas 9

Control

Exon_4_LATS2

LATS 2 gRNA 1

*LATS2_gRNA_2_477bp_band

LATS2_gRNA_2_649bp_band

LATS2_gRNA 3

Cas 9

Control

Exon_4_LATS2

LATS 2 - gRNA 1

* LATS2 gRNA 2 477bp band LATS2_gRNA_2_649bp_band LATS2_gRNA_3

Cas 9

Control

Exon_4_LATS2

LATS2 GRNA 1

* LATS2_gRNA_2_477bp_band

LATS2_gRNA_2_649bp_band

LATS2_gRNA_3

Cas 9

Control

Exon 4 LATS2

LATS 2 - gRNA 1

* LATS2_gRNA_2_477bp_band

LATS2_gRNA_2_649bp_band LATS2_gRNA_3

Cas 9

Control

Exon_4_LATS2

LATS 2 - gRNA 1

* LATS2 gRNA 2 477bp band

LATS2_gRNA_2_649bp_band

LATS2 gRNA 3
CCCATGGGACCCATCCAGTGTGACCCTGTCCTGTCCCTCCTGCCCCCATG CCCATGGGACCCATCCAGTGTGACCCTGTCCTGTCCCTCCTGCCCCCATG CCCAGGGGACCCATCCAGTGTGACCCTGTCCTGTCCCTCCTGCCCCCATG CCCATGGGACCCATCCAGTGTGACCCTGTCCTGTCCCTCCTGCCCCCATG C------TGCTGGTTGAGCACGACAC-GCCCTGTTGCGCACGCG-CAGCG CCCATGGGACCCATCCAGTGTGACCCTGTCCTGTCCCTCCTGCC-СCATG CCCATGGGACCCATCCAGTGTGACCCTGTCCTGTCCCTCCTGCCCCCATG

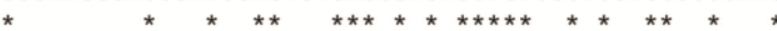

GGGCCTGTCCAGT-GTGACCCTGTCCTGTTTCCTCCTGCACAGGCCGGGC GGGCCTGTCCAGT-GTGACCCTGTCCTGTTTCCTCCTGCACAGGCCGGGC GGGCCTGTCCAGT-GTGACCCTGTCCTGTTTCCTCCTGCACAGGCCGGGC GGGCCTGTCCAGT-GTGACCCTGTCCTGTTTCCTCCTGCACAGGCCGGGC GGGTC-GTTCACAAATGGGCC-----------ACGGAGCCGGCCA-GC GGGCCTGTCCAGT-GTGACCCTGTCCTGTTTCCTCCTGCACAGGCCGGGC GGGCCTGTCCAGT-GTGACCCTGTCCTGTTTCCTCCTGCACAGGCCGGGC

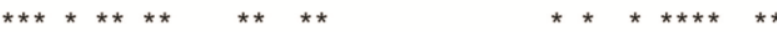

TCTGTGAGGCCGAGCAGGAGCAGATGAGGAAGATTCTTTACCAGAAGGAG TCTGTGAGGCCGAGCAGGAGCAGATGAGGAAGATTCTTTACCAGAAGGAG TCTGTGAGGCCGAGCAGGAGCAGATGAGGAAGATTCTTTACCAGAAGGAG TCTGTGAGGCCGAGCAGGAGCAGATGAGGAAGATTCTTTACCAGAAGGAG TCGGCCAGGCGGCGCG------------------TCACCATTGGATC TCTGTGAGGCCGAGCAGGAGCAGATGAGGAAGATTCTTTACCAGAAGGAG TCTGTGAGGCCGAGCAGGAGCAGATGAGGAAGATTCTTTACCAGAAGGAG

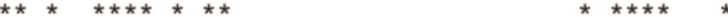

TCCAATTACAATAGGCTCAAGCGGGCCAAGATGGACAAGTCCATGTTTGT TCCAATTACAATAGGCTCAAGCGGGCCAAGATGGACAAGTCCATGTTTGT TCCAATTACAATAGGCTCAAGCGGGCCAAGATGGACAAGTCCATGTTTGT TCCAATTACAATAGGCTCAAGCGGGCCAAGATGGACAAGTCCATGTTTGT GCCGATCGCCAGGTGCT-----GGGCGAGGGCTGCGAAATGCGCGGT-CT TCCAATTACAATAGGCTCAAGYGGGCCAAGATGGACAAGTCCATGTTTGT TCCAATTACAATAGGCTCAAGCGGGCCAAGATGGACAAGTCCATGTTTGT

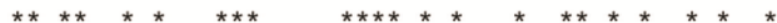

GAAGGTGAAGACCCTGGGCGTTGGCGCCTTTGGGGAGGTGTGCCTGGCCT GAAGGTGAAGACCCTGGGCGTTGGCGCCTTTGGGGAGGTGTGCCTGGCCT GAAGGTGAAGACCCTGGGCGTTGGCGCCTTTGGGGAGGTGTGCCTGGCCT GAAGGTGAAGACCCTGGGCGTTGGCGCCTTTGGGGAGGTGTGCCTGGCCT GGCGCTGCGCAACGAGGGTGTTGATCC----AGGCCGATCCCAGCAGGCT GAAGGTGAAGACCCTGGGCGTTGGCGCCTTTGGGGAGGTGTGCCTGGCCT GAAGGTGAAGACCCTGGGCGTTGGCGCCTTTGGGGAGGTGTGCCTGGCCT * * ** * * $* * * * * * \quad * \quad * * * * * * *$

GCAAGGTGGACACGCACG-CGCTGTATGCCATGAAGACCCTTAGAAAGAGCAAGGTGGACACGCACG-CGCTGTATGCCATGAAGACCCTTAGAAAGAGCAAGGTGGACACGCACG-CGCTGTATGCCATGAAGACCCTTAGAAAGAGCAAGGTGGACACGCACG-CGCTGTATGCCATGAAGACCCTTAGAAAGAGCC--GAGGAATTGCGCGCCGCTGAAGGCGGCCAAAAAGCTCACCATGTG GCAAGGTGGACACGCACG-CGCTGTATGCCATGAAGACCCTTAGAAAGAGCAAGGTGGACACGCACG-CKCTGTATGCCATGAAGACCCTTAGAAAGA-

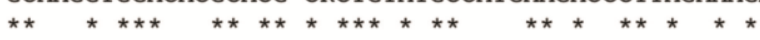

-AGGACGTCCTGAACCGCAACCAGGTGGCCCACGTCAAGGCAGAGCGGGA -AGGACGTCCTGAACCGCAACCAGGTGGCCCACGTCAAGGCAGAGCGGGA -AGGACGTCCTGAACCGCAACCAGGTGGCCCACGTCAAGGCAGAGCGGGA -AGGACGTCCTGAACCGCAACCAGGTGGCCCACGTCAAGGCAGAGCGGGA CCGGCCACCCT--CCCGCAACACG--GGCCCA-----AAGCCCTGCAG--AGGACGTCCTGAACCGCAACCAGGTGGCCCACGTCAAGGCAGAGCGGGA -AGGACGTCCTGAACCGCAACCAGGTGGCCCACGTCAAGGCAGAGCGGGA

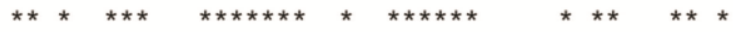

CATCCTGGCGGAGGCGGACAATGAATGGGTAGTCAAGCTCTACTACTCCT CATCCTGGCGGAGGCGGACAATGAATGGGTAGTCAAGCTCTACTACTCCT CATCCTGGCGGAGGCGGACAATGAATGGGTAGTCAAGCTCTACTACTCCT CATCCTGGCGGAGGCGGACAATGAATGGGTAGTCAAGCTCTACTACTCCT CA-----GC-GAGGCTGAAAAA-AACAG--ACCCAAGCCGGCGGAC---A CATCCTGGCGGAGGCGGACAATGAATGGGTAGTCAAGCTCTACTACTCCT CATCCTGGCGAGGCGGAAATE-- GGGTGGTCAAGCTCTACTACTCCT ** $* * * * * * * * * * * * * * * * * *$

Legenda: pontilhados (----) - bases que não se alinham; asterisco (*) - nucleotídeos iguais em todas as sequências; asterisco na cor verde $(*)$ - evidencia o sequenciamento da amostra gRNAe2; retângulo em vermelho $(\square)$ - evidencia os 4 pares de base alterados na amostra gRNAe3. 
4.5 Repetição do experimento pós-quarentena da COVID-19

Visando aumentar o número de replicatas no retorno gradual após o pico da pandemia, foram realizadas microinjeções em oócitos presumivelmente em MII. Foram realizadas 4 replicatas desta maneira, com a divisão de grupos experimentais idêntica ao experimento anterior. Entretanto, a taxa de blastocistos no grupo controle foi baixa, impedindo a realização de qualquer análise ou inferência sobre os resultados e embriões ou estruturas produzidas (tabela 3).

Tabela 3 - Taxas de clivagem, formação de blastocistos e desenvolvimento, oriundos da segunda fase de manipulações.

\begin{tabular}{lcccccc}
\hline Grupo & Data & Replicata & Zigotos & Clivagem & Blastocistos & Desenvolvimento \\
\cline { 5 - 7 } & & & & \multicolumn{3}{c}{ Taxas (\%) } \\
\cline { 5 - 7 } Controle & $13 / 07 / 2020$ & $1^{\text {a }}$ & 40 & 63 & 3 & 4 \\
Controle & $20 / 07 / 2020$ & $2^{\text {a }}$ & 40 & 75 & 0 & - \\
Controle & $27 / 07 / 2020$ & $3^{\text {a }}$ & 41 & 73 & 5 & 7 \\
Controle & $03 / 08 / 2020$ & $4^{\text {a }}$ & 41 & 51 & 2 & 5 \\
\hline Cas 9 & $13 / 07 / 2020$ & $1^{\text {a }}$ & 38 & 18 & 0 & - \\
Cas 9 & $20 / 07 / 2020$ & $2^{\text {a }}$ & 33 & 36 & 0 & - \\
Cas 9 & $27 / 07 / 2020$ & $3^{\text {a }}$ & 39 & 21 & 0 & - \\
Cas 9 & $03 / 08 / 2020$ & $4^{\text {a }}$ & 41 & 29 & 2 & - \\
gRNA Lats & $13 / 07 / 2020$ & $1^{\text {a }}$ & 29 & 3 & 0 & - \\
gRNA Lats & $20 / 07 / 2020$ & $2^{\text {a }}$ & 38 & 45 & 0 & 8 \\
gRNA Lats & $27 / 07 / 2020$ & $3^{\text {a }}$ & 39 & 56 & 0 & - \\
gRNA Lats & $03 / 08 / 2020$ & $4^{\text {a }}$ & 39 & 33 & 3 & - \\
\hline
\end{tabular}

Com o retorno parcial às atividades, foi possível retomar injeções após 10h de FIV. Houve redução no número de células nas estruturas do grupo injetado com LATS2 gRNA. Os dados obtidos na contagem de células estão inseridos no gráfico 2. Entretanto, as taxas de blastocisto do grupo controle continuaram baixas o que impediu aproveitamento dessas manipulações para análises posteriores (tabela 4). 
Tabela 4 - Taxas de clivagem, formação de blastocistos e desenvolvimento, oriundos da terceira fase de manipulações.

\begin{tabular}{|c|c|c|c|c|c|c|}
\hline \multirow[t]{2}{*}{ Grupo } & \multirow[t]{2}{*}{ Data } & \multirow[t]{2}{*}{ Replicata } & \multirow[t]{2}{*}{ Zigotos } & Clivagem & Blastocistos & Desenvolvimento \\
\hline & & & & \multicolumn{3}{|c|}{$\operatorname{Taxas}(\%)$} \\
\hline Controle & $19 / 08 / 2020$ & $1^{\mathrm{a}}$ & 42 & 60 & 12 & 20 \\
\hline Controle & $26 / 08 / 2020$ & $2^{\mathrm{a}}$ & 27 & 30 & 7 & 25 \\
\hline Controle & 02/09/2020 & $3^{\mathrm{a}}$ & 46 & 72 & 9 & 12 \\
\hline Controle & 09/09/2020 & $4^{\mathrm{a}}$ & 46 & & & \\
\hline Cas 9 & $19 / 08 / 2020$ & $1^{\mathrm{a}}$ & 41 & 15 & 0 & - \\
\hline Cas 9 & $26 / 08 / 2020$ & $2^{\mathrm{a}}$ & 28 & 32 & 0 & - \\
\hline Cas 9 & 02/09/2020 & $3^{\mathrm{a}}$ & 43 & 44 & 0 & - \\
\hline Cas 9 & $09 / 09 / 2020$ & $4^{\mathrm{a}}$ & 45 & & & \\
\hline gRNA Lats & $19 / 08 / 2020$ & $1^{\mathrm{a}}$ & 39 & 31 & 3 & 8 \\
\hline gRNA Lats & $26 / 08 / 2020$ & $2^{\mathrm{a}}$ & 30 & 50 & 0 & - \\
\hline gRNA Lats & $02 / 09 / 2020$ & $3^{\mathrm{a}}$ & 45 & 44 & 0 & - \\
\hline gRNA Lats & 09/09/2020 & $4^{\mathrm{a}}$ & 41 & & & \\
\hline
\end{tabular}

Gráfico 2 - Contagem de células após coloração por hoechst nos embriões acima de 16 células microinjetados às 10h após a inseminação in vitro.

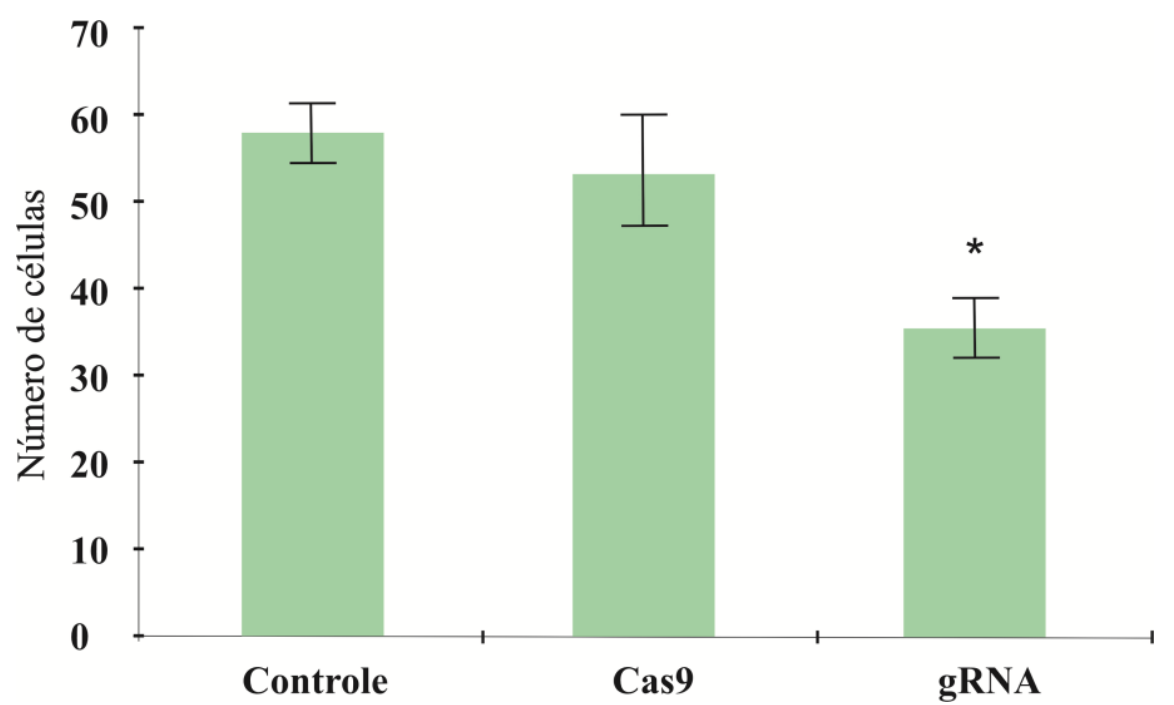

Legenda: os dados em (C) foram analisados por ANOVA seguidos de comparação de médias com teste de Tukey. Asterisco indica diferença estatística significativa $(p<0,05)$. 


\section{DISCUSSÃO}

A diferenciação e a especialização celular são processos iniciais do desenvolvimento embrionário bovino, que culminam da especificação de células da MCI, que darão origem ao feto propriamente dito e ao TE, que dará origem a placenta e anexos, formando assim o blastocisto (Gardner, 1989; Frankenberg et al., 2016). Essa especialização é designada por alterações bioquímicas, incluindo a expressão de genes específicos, que estabelecem as alterações fenotípicas celulares. A via de sinalização HIPPO é uma via de sinalização considerada altamente conservada com funções bem definidas no controle do crescimento de órgãos, na diferenciação celular, proliferação e apoptose, nas espécies em que já foi bem definida, como em camundongos (Halder e Johnson, 2011; Meng et al., 2016). Ela está frequentemente associada a estudos relativos a processos de apoptose e crescimento tumoral. Contudo, ao longo das descobertas sobre as cascatas de fosforilações presentes na via, diferentes trabalhos a citam como fator importante em processos reprodutivos de mamíferos (Hall et al., 2010; Li et al., 2012). A via de sinalização HIPPO vem sendo estudada em diferentes tecidos celulares (Yu e Guan, 2013; Meng et al., 2016), inclusive durante o processo de embriogênese (Manzanares e Rodriguez, 2013; Frum et al., 2018).

Sabe-se em bovinos que a via está presente e pode ter uma influência direta ou indireta sobre os processos da embriogênese (Tribulo et al., 2017; Sakurai et al., 2017; Sharma \& Madan, 2019), porém, o funcionamento e a regulação das fosforilações ainda não é totalmente compreendido. Sharma \& Madan (2019) confirmam a presença de constituintes da via de sinalização de HIPPO, como YAP, no embrião bovino nos primeiros estágios de desenvolvimento. Tribulo et al. (2017) demonstraram a localização de YAP1 e CDX2 no TE de blastocistos bovinos. Contudo, haja vista a presença concomitante de YAP e CDX2 no TE bovino, é plausível que a via HIPPO possa participar na diferenciação celular bovina, com YAP participando como co-ativador de outros fatores de transcrição.

A hipótese do presente estudo foi de que a deleção de LATS2 resultaria em um desenvolvimento embrionário sem definição da MCI em decorrência da inativação da cascata de fosforilações da via HIPPO, dependente da ação quinase de LATS. O pressuposto baseouse nas considerações da literatura, determinando os objetivos de deletar, via sistema CRISPR/Cas9, a sequência do gene LATS2 relativa à função quinase, afim de inativar as cascatas de fosforilações, impedindo assim a diferenciação celular no estágio inicial do desenvolvimento embrionário bovino.

Os resultados considerados para o presente estudo foram os obtidos na primeira fase de manipulações, que contou com 3 replicatas. Os dados de cultivo embrionário e as 
avaliações em dia 8 demonstraram que houve uma alteração no desenvolvimento embrionário das estruturas do grupo gRNA - zigotos microinjetados 10 horas após a fertilização in vitro com os gRNAs para o gene LATS e proteína Cas9 -, havendo distinção morfológica, sugestivo bloqueio ou morte embrionária na fase de 16 células, gerando estruturas semelhantes a mórulas. Contudo, a contagem de células após coloração de núcleos com Hoechst evidenciou um número de células acima de 16, sugerindo que esses embriões superaram o bloqueio na fase da ativação genômica (Badr et al., 2007). De qualquer maneira, houve diminuição em números de células nas estruturas do grupo gRNA, quando comparadas as dos grupos controle e Cas9, sendo sugestivo de alteração já nas fases iniciais da clivagem celular.

Cockburn e Rossant (2010) ilustram que YAP está presente no núcleo de células do trofectoderma e no citoplasma de células da massa celular interna de camundongos. Seguindo esse princípio e de acordo com os resultados obtidos na imunofluorescência para YAP, houveram duas situações distintas para o grupo gRNA, no qual houve formação de uma estrutura com morfologia de blastocisto, tendo marcações características para YAP e que pode não ter sido microinjetado corretamente ou não houve ação do sistema CRISPR/Cas9, sendo posteriormente confirmado por genotipagem que não foi editado. Na outra situação, as estruturas semelhantes a mórulas não demonstraram marcações para YAP, e que acreditou-se ser estruturas microinjetadas corretamente e como consequência, editadas geneticamente, fato confirmado por PCR e sequenciamento.

As junções de aderência e a aquisição de polaridade apical-basal ocorrem no estágio de 8 células, no início do desenvolvimento embrionário, sendo este evento denominado compactação (Cockburn e Rossant, 2010). À medida que estas células se dividem, as mais íntimas e mais compactas perdem a sua polaridade, e as suas diferenças em relação às células exteriores resultam numa distribuição díspar de YAP. Sharma \& Madan (2019) confirmam a presença dos constituintes da via de sinalização de HIPPO, como o YAP no embrião bovino durante todas as fases da embriogênese, estando presente tanto nos estágios pré como na póscompactação. Baseando-se nessas afirmações, pode-se levar em consideração que mesmo em uma possível parada na fase de 16 células, anteriormente a isso ocorreria a marcação em decorrência da presença de YAP, porém, não houve marcações na imunofluorescência. Esses resultados são sugestivos de que as estruturas do grupo gRNA que não chegaram até a fase de blastocisto no $8^{\circ}$ dia de cultivo, tiveram seu material genético alterado e como consequência, o não desenvolvimento, culminando talvez em morte celular. Não houveram alterações para a presença de YAP em grupos controle ou apenas microinjetados com Cas9. 
Após a imunofluorescência, as mesmas estruturas tiveram seu DNA extraído para a realização da genotipagem via PCR e posterior comparação dos resultados com a imunofluorescência. Foi realizada a eletroforese dos produtos da PCR e analisados os resultados em gel de agarose. A banda intacta do gene LATS conta com 650 pares de base, enquanto uma estrutura deletada para LATS — com os RNAs guia construídos para a edição desse projeto - conta com 477 pares de base. O DNA de uma amostra — de 3 analisadas do grupo gRNA, denominada gRNA e2 na imunofluorescência, apresentou uma banda de aproximadamente 650 pares de base e outra banda de aproximadamente 470 pares de base.

O sequenciamento confirmou a alteração no embrião gRNAe2, no qual houve uma exclusão de pares de base referentes a porção quinase da proteína LATS. Porém, esse mesmo embrião, apresentou, além da banda de 477 pares de bases com alteração genômica, uma banda de 650 pares de base, intactos, como nos embriões controle. Isso pode ser consequência de um corte em apenas um dos alelos. Se houvesse o corte em dois alelos, haveria uma única banda de 477 pares de base. A banda superior, ilustrada na figura 8, com 650 pares de base, demonstra um alelo que não foi modificado ou ainda, é possível que o sistema CRISPR/Cas9 tenha editado apenas o genoma materno e não paterno ou vice e versa, como observado em humanos (Ma et a. 2017). Apesar da microinjeção ter sido realizada às 10 horas após a FIV para início das manipulações, existe a possibilidade de que a estrutura tenha iniciado a sua multiplicação do conteúdo genético para a primeira divisão celular, e, consequentemente, a Ca9 tenha atingido apenas alguma cópia dos alelos, culminando em um mosaicismo.

Ainda, observou-se deleção de 4 pares de base em região próxima ao alvo do gRNA2 no embrião gRNAe3, onde nota-se, no sequenciamento, uma tentativa de reparo da célula com um erro nos 4 pares de base (figura 9). Apesar da genotipagem da estrutura gRNAe3 não ter evidenciado na eletroforese uma alteração em bandas, o corte dos 4 pares de base próximo ao alvo do RNA guia 2, provavelmente culminou em uma alteração proteica. Caso houvessem apenas 3 pares de base alterados, o corte alteraria apenas um aminoácido, porém, o resultado é sugestivo de alteração proteica. Apesar de ser uma alteração significativa, em relação as bases alteradas, é uma alteração pequena, podendo não ser evidenciada em gel após a eletroforese. Análises posteriores poderão confirmar essas alterações e qual a proteína afetada.

Esses resultados evidenciam o sucesso da técnica de edição gênica via sistema CRISPR/Cas9 e conclui que houve de fato a deleção da porção quinase do gene LATS2 no embrião bovino, resultando em uma estrutura sem definição morfológica e sem especialização celular. Esses dados corroboram com demais estudos que demonstram a atividade da via 
HIPPO desde os primeiros mecanismos do desenvolvimento embrionário bovino (Tribulo et al., 2017; Sakurai et al., 2017; Sharma \& Madan, 2019; Tsoi et al., 2019).

Durante o desenvolvimento da pesquisa, houveram problemas metodológicos, que culminaram na inviabilidade de uso dos dados de 8 replicatas. Inicialmente, houve a necessidade de interrupção temporária do projeto, que durou mais de 4 meses, em decorrência da quarentena estabelecida devido à pandemia de COVID-19. Após a retomada das atividades, não foi possível dar sequência à pesquisa com os mesmos horários estipulados inicialmente na metodologia, havendo uma adaptação das microinjeções para o estágio de metáfase II, anteriormente à FIV. Contudo, as avaliações durante o cultivo embrionário após a microinjeção evidenciaram a morte das estruturas de todos os grupos, incluindo o controle, que não foi microinjetado, mas passou pelas demais manipulações precoces. A manipulação precoce das estruturas, em decorrência da necessidade de ser retirado o excesso de células para o sucesso da microinjeção anteriormente a FIV, pode ter colaborado para esse resultado. Logo após a liberação de acesso ao departamento em horários noturnos, foram retomadas as microinjeções 10 horas após a FIV. Porém, uma alteração no óleo do cultivo embrionário causou a morte da maioria das estruturas, incluindo parte do grupo controle, que tiveram uma maior sobrevivência, porém, ainda assim, sendo estruturas com qualidade morfológica inferior. As estruturas microinjetadas tanto para o grupo gRNA quanto para o grupo Cas9, sensibilizadas pela manipulação, não resistiram ao cultivo, o que tornou os dados obtidos não aproveitáveis. 


\section{CONCLUSÃO}

Os objetivos da pesquisa foram o de compreender a função do gene LATS2, sua influência sobre a segregação entre MCI e o TE em bovinos, de modo a inativar a ação da via HIPPO durante o desenvolvimento embrionário bovino.

Apesar das intercorrências que impossibilitaram o uso de um número maior de amostras para as análises, o sequenciamento de estruturas editadas evidenciou a deleção de uma porção do gene e corrobora com a hipótese de influência da via sobre o desenvolvimento embrionário bovino e da ação de LATS na espécie, relacionando-o ao desenvolvimento e especialização celular na embriogênese, assim como em outras espécies de mamíferos.

A ampla importância da via HIPPO na diferenciação e especialização celular é refletida em decorrência da complexa rede de sinais que controlam a atividade de TAZ e YAP e estes por sua vez, tem papéis-chave em coordenar o destino celular, a proliferação e a apoptose (Varelas, 2014). Os resultados do presente estudo sugerem que a via HIPPO possui papel significativo na diferenciação de MCI e TE em embriões bovinos e que o gene LATS2 estaria diretamente ligado a cascata de fosforilações da via nessa espécie. Contudo, estudos mais aprofundados sobre os demais efetores da via são necessários para uma total interpretação das fosforilações e subsequente influência na expressão de genes que culminam na diferenciação e especialização celular durante a embriogênese bovina. 


\section{REFERÊNCIAS}

ALANIS-LOBATO, G.; ZOHREN, J.; MCCARTHY, A.; FOGARTY, N. M. E.; KUBIKOVA, N.; HARDMAN, E.; GRECO, M.; WELLS, D.; TURNER, J. M. A.; NIAKAN, K. K. Frequent loss-of-heterozygosity in CRISPR-Cas9-edited early human embryos. BioRxiv, 06.05.135913, 2020.

AMOASII, L.; HILDYARD, JCW.; LI, H.; SANCHEZ-ORTIZ, E.; MIREAULT, A.; CABALlERO, D.; HARRON, R.; STATHOPOULOU, T. R.; MASSEY, C.; SHELTON, J. M.; BASSEL-DUBY, R.; PIERCY, RJ.; OLSON, E. N. Gene editing restores dystrophin expression in a canine model of Duchenne muscular dystrophy. Science, V. 362, 86-91. 05 oct 2018.

ANDERS, C.; NIEWOEHNER, O.; DUERST, A.; JINEK, M. Structural basis of PAMdependent target DNA recognition by the Cas9 endonuclease. Nature, V. 513 (7519): 569573. 2014.

ANZALONE, A. V.; RANDOLPH, P. B.; DAVIS, J. R.; SOUSA, A. A.; KOBLAN, L.W.; LEVY, J. M.; CHEN, P. J.; WILSON, C.; NEWBY, G. A.; RAGURAM, A.; LIU, D. R. Search-and-replace genome editing without double-strand breaks or donor DNA. Nature, V.576, 149-157. 2019.

BADR, H.; BONGIONI, G.; ABDOON, A. S. S.; KANDIL, O.; PUGLISI, R. Gene expression in the in vitro-produced preimplantation bovine embryos. Zygote, Cambridge, v. 15, p.355-67, 2007.

BARRANGOU, R.; FREMAUX, C.; DEVEAU, H.; RICHARDS, M.; BOYAVAL, P.; MOINEAU, S.; ROMERO, D. A.; HORVATH, P. CRISPR provides acquired resistance against viruses in prokaryotes. Science, V 315, 1709-1712. 2007.

BEVACQUA, RJ.; MARTÍN, R. F.; SAVY, V.; CANEL, N. G.; GISMONDI, M. I.; KUES, W. A.; CARLSON, D. F.; FAHRENKRUG, S. C.; NIEMANN, H.; TABOGA, O. A.; FERRARIS, S,; SALAMONE, D. F. Efficient edition of the bovine PRNP prion gene in 
somatic cells and IVF embryos using the CRISPR/Cas9 system. Theriogenology, V. 86, 1886-1896. 2016.

BOGLIOTTI, Y. S.; WU, J.; VILARINO, M.; OKAMURA, D.; SOTO, D. A.; ZHONG, C.; SAKURAI, M.; SAMPAIO, R. V.; SUZUKI, K.; BELMONTE, J. C. I.; ROSS, P. J. Efficient derivation of stable primed pluripotente embryonic stem cells from bovine blastocysts. PNAS, V. 115 (9) 2090-2095 February 27, 2018.

BOLOTIN, A.; QUINQUIS, B.; SOROKIN, A.; EHRLICH, S. D. Clustered regularly interspaced short palindrome repeats (CRISPRs) have spacers of extrachromosomal origin. Microbiology, V. 151(Pt 8):2551-2561. Aug, 2005.

BOND, G. B.; ALMEIDA, R.; OSTRENSKY, A.; MOLENTO, A. F. M. Métodos de diagnóstico e pontos críticos de bem-estar de bovinos leiteiros. Ciência Rural, Santa Maria, v.42, p.1286-1293. 2012.

BONNY, S. Why are most Europeans opposed to GMOs? Factors explaining rejection in France and Europe. Electronic Journal of Biotechnology, V. 6 No. 1, Issue of April 15, $2003 . \quad$ Disponível em: http://www.ejbiotechnology.info/index.php/ejbiotechnology/article/view/v6n1-4/573. Acesso em 07 de abril de 2020.

Brasil. Lei $\mathrm{n}^{\circ}$ 11.105, de 24 de março de 2005. Presidência da República. Disponível em: http://www.planalto.gov.br/ccivil_03/_Ato2004-2006/2005/Lei/L11105.htm. Acesso em 10 de julho de 2020.

Brasil. Resolução Normativa $\mathrm{n}^{0}$ 24, de 07 de janeiro de 2020. Ministério da Ciência, Tecnologia, Inovações e Comunicações/Comissão Técnica Nacional de Biossegurança. Disponível em http://www.in.gov.br/en/web/dou/-/resolucao-normativa-n-24-de-7-de-janeirode-2020-237272300. Acesso em 10 de julho de 2020.

BRAZELTON, V. A. JR.; ZARECOR, S.; WRIGHT, D. A.; WANG, Y.; LIU, J.; CHEN, K.; YANG, B.; LAWRENCE-DILL, C. J. A quick guide to CRISPR sgRNA design tools. GM Crops Food, 6(4):266-76. 2015. 
BRINSTER, R. L.; CHEN, H. Y.; TRUMBAUER, M. E.; YAGLET, M. K.; PALMITER, R. D. Factors affecting the efficiency of introducing foreign DNA into mice by microinjecting eggs. PNAS, 82(13): 4438-42. Jul, 1985.

BROUNS, S. J.; JORE, M. M.; LUNDGREN, M.; WESTRA, E. R.; SLIJKHUIS, R. J.; SNIJDERS, A. P.; DICKMAN, M. J.; MAKAROVA, K. S.; KOONIN, E. V.; VAN, D. O. J. SMALL CRISPR RNAs guide antiviral defense in prokaryotes. Science, V. 321, 960-964. 2008 .

CALLAWAY, E. CRISPR plants now subject to tough GM laws in European Union. Nature, News in Focus. 560(7716):16. 2018.

CALlUS, B. A.; VERHAGEN, A. M.; VAUX, D. L. Association of mammalian sterile twenty kinases, Mst1 and Mst2, with hSalvador via C-terminal coiled-coil domains, leads to its stabilization and phosphorylation. The Febs Journal, V. 273, n ${ }^{\circ}$ 18, 4264-76, (Print), 1742-464x. Sep, 2006.

CAO, S.; WANG, F.; CHEN, Z.; LIU, Z.; MEI, C.; WU, H.; HUANG, J.; LI, C.; ZHOU, L.; LIU, L. Isolation and Culture of Primary Bovine Embryonic Stem Cell Colonies by a Novel Method. Journal of Experimental Zoology, 311A:368-376. 2009.

CARLSON, D. F.; LANCTO, C. A.; ZANG, B.; KIM, E. S.; WALTON, M.; Oldeschulte, D.; SEABURY, C.; SONSTEGARD, T. S.; FAHRENKRUG, S. C. Production of hornless dairy cattle from genome-edited cell lines. Nature Biotechnology, 6;34(5):479-81. May, 2016.

CHAN, A. W. S.; KUKOLJ, G.; SKALKA, N. A.; BREMEL, R. D. Timing of DNA Integration, Transgenic Mosicism, and Pronuclear Microinjection. Molecular Reproduction and Development, 52:406-413. 1999.

CIBELLI, J. B.; STICE, S. L.; GOLUEKE, P. J.; KANE, J. J.; JERRY, J.; BLACKWELL, C.; LEÓN, F. A. P.; ROBL, J. M. Transgenic bovine chimeric offspring produced from somatic cell-derived stem-like cells. Nature Biotechnology, V.16, 642-646. Jul,1998. 
COCKBURN, K.; ROSSANT, J. Making the blastocyst: lessons from the mouse. The Journal of Clinical Investigation, V. 120, 995-1003. 2010.

CONG, F., RAN, A., COX, D., LIN, S., BARRETTO, R., HABIB, N., HSU, P. D., WU, X., JIANG, W., MARRAFFINI, L., ZHANG, F. Multiplex Genome Engineering Using CRISPR/Cas Systems. Science, V. 15, 339 (6121), 819-23. 2013.

CRISPO, M.; MULET, A. P.; TESSON, L.; BARRERA, N.; CUADRO, F.; DOS SANTOSNETO, P. C.; NGUYEN, T. H.; CRÉNÉGUY, A.; BRUSSELlE, L.; ANEGÓN, I.; MENCHACA, A. Efficient Generation of Myostatin Knock-Out Sheep Using CRISPR/Cas9 Technology and Microinjection into Zygotes. PLos One, 25;10(8):e0136690. Aug, 2015.

DAIGNEAULT, B. W., SANDEEP, R., SMITH, G. W., ROSS, P. J. Embryonic POU5F1 is Required for Expanded Bovine Blastocyst Formation. Scientific Reports, V. 8, no 7753. 2018.

EZASHI, T.; YUAN, Y.; ROBERTS, R. M. Pluripotent Stem Cells, from Domesticated Mammals. Annual review of animal biosciences, V. 4, 223-253. Feb, 2015.

FARIN, P. W., FARIN, C. E. Transfer of bovine embryos produced in vivo or in vitro: survival and fetal development. Biology of Reproduction, V. 52, 676-682, 1995.

FILHO, K. E.; ALENCAR, M. M.; CEZAR, I. M.; FÁVERO, J. A.; VASCONCELOS, V. R.; COLLARES, R. S. Cadeias produtivas como plataformas para o desenvolvimento da ciência, da tecnologia e da inovação / Kepler Euclides Filho [et al.]. Campo Grande: Embrapa Gado de Corte, 133 p. 2002.

FISCHER, K.; KRANER-SCHEIBER， S.; PETERSEN， B.; RIEBLINGER, B.; BUERMANN, A.; FLISIKOWSKA, T,; FLISIKOWSKI, K.; CHRISTAN, S.; EDLINGER, M.; BAARS, W.; KUROME, M.; ZAKHARTCHENKO, V.; KESSLER, B.; PLOTZKI, E.; SZCZERBAL, I.; SWITONSKI, M.; DENNER, J.; WOLF, E.; SCHWINZER, R.; NIEMANN, H.; KIND, A.; SCHNIEKE, A. Efficient production of multi-modified pigs for xenotransplantation by 'combineering', gene stacking and gene editing. Scientific Reports, V.6, nº 29081. 2016. 
FRANKENBERG, S. R., DE BARROS, F. R. O., ROSSANT, J., RENFREE, M. B. The mammalian blastocyst. Wires Developmental Biology, V. 5, 210-232. 2016.

FRIEDLAND, A. E.; BARAL, R.; SINGHAL, P.; LOVELUCK, K.; SHEN, S.; SANCHEZ, M.; MARCO, E.; GOTTA, G. M.; MAEDER, M. L.; KENNEDY, E. M.; KORNEPATI, A. V. R.; SOUSA, A.; COLlinS, M. A.; JAYARAM, H.; CULlEN, B. R.; BUMCROT, D. Characterization of Staphylococcus aureus Cas9: a smaller Cas9 for all-in-one adenoassociated virus delivery and paired nickase applications. Genome Biology, V.16, nº257. 2015 .

FRUM, T.; MURPHY, T. M.; RALSTON, A. HIPPO signaling resolves embryonic cell fate conflicts during establishment of pluripotency in vivo. Elife, V. 7, e42298. Dec, 2018.

GAO, X.; TAO, Y.; LAMAS, V.; HUANG, M.; YEH, W. H.; PAN, B.; HU, Y. J.; HU, J. H.; THOMPSON, D. B.; SHU, Y.; LI, Y.; WANG, H.; YANG, S.; XU, Q.; POLLEY, D. B.; LIBERMAN, M. C.; KONG, W. J.; HOLT, J. R.; CHEN, Z. Y.; LIU, D. R. Treatment of autosomal dominant hearing loss by in vivo delivery of genome editing agents. Nature, V. 553, 217-221. 2018.

GARDNER, R. L. Cellular basis of morphogenesis. CIBA Foundation Symposium, V. 144, $172-181,1989$.

GASIUNAS, G.; BARRANGOU, R.; HORVATH, P.; SIKSNYS, V. Cas9-crRNA ribonucleoprotein complex mediates specific DNA cleavage for adaptive immunity in bactéria. PNAS, V. 109 (39) E2579-E2586. Sep, 2012.

GEORGES, M.; CHARLIER, C.; HAYES, B. Harnessing genomic information for livestock improvement. Nature Reviews Genetics, V. 20, 135-156. 2019.

GOISSIS, M. D., CIBELLI, J. B. Functional characterization of SOX2 in bovine preimplantation embryos. Biology of Reproduction, V. 90 (2):30, 1-10. 2014.

GONÇALVES, G. A. R.; PAIVA, R. M. A. Terapia gênica: avanços, desafios e perspectivas. Einstein, V.15 no.3, São Paulo. 2017. 
GONZÁLEZ, J. E. G. Alimentos genéticamente alterados: transgénico. Revista Biocenosis, V. $21, n^{\circ} 1-2.2008$.

GRISSA, I.; VERGNAUD, G.; POURCEL, C. The CRISPRdb database and tools to display CRISPRs and to generate dictionaries of spacers and repeats. BMC Bioinformatics, V.8, $\mathrm{n}^{\circ} 172.2007$.

Guide Design Resources. In: Zhang Lab website, Broad Institute, MA, EUA. Disponível em $<$ https://zlab.bio/guide-design-resources>. Acesso em 29 de julho de 2020.

HALDER, G.; JOHNSON, R. L. Hippo signaling: growth control and beyond. Development, V. 138, nº 1, 9-22, ISSN 0950-1991. Jan, 2011.

HALL, C. A.; WANG, R.; MIAO, J.; OLIVA, E.; SHEN, X.; WHEELER, T.; HILSENBECK, S. G.; ORSULIC, S.; GOODE, S. Hippo pathway effector Yap is an ovarian cancer oncogene. Cancer Research, V. 70 (21), 8517-25. Epub, 2010.

HAO, Y., CHUN, A., CHEUNG, K., RASHIDI, B., YANG, X. Tumor suppressor LATS1 is a negative regulator of oncogene YAP. Journal of Biological Chemistry, V. 283, $\mathrm{n}^{\circ}$ 9, 5496509. ISSN 0021-9258 (Print), 0021-9258. Feb, 2008.

HARDY, K. H.; HANDYSIDE, A. H., WINSTON, R. M. L. The human blastocyst: cell number, death and allocation during late preimplantation development. Development, V. 107, 597-604. 1989.

HARMSEN, T.; KLAASEN, S.; VRUGT, H. V.; RIELE, H. T. DNA mismatch repair and oligonucleotide end-protection promote base-pair substitution distal from a CRISPR/Cas9induced DNA break. Nucleic Acids Research, V.46, (6):2945-2955. Apr, 2018.

HAVLICEK, S.; SHEN, Y.; ALPAGU, Y.; BRUNTRAEGER, M. B.; ZUFIR, N. B. M.; FU, Z.; LAWRENCE, N. R.; STANTON, W. Re-engineered RNA-Guided FokI-Nucleases for Improved Genome Editing in Human Cells. Molecular Therapy, V. 25, (2):342-355. 2017. 
HELLMICH, R.; SID, H.; LENGYEL, K.; FLISIKOWSKI, K.; SCHLICKENRIEDER, A.; BARTSCH, D.; THOMA, T.; BERTZBACH, L. D.; KAUFER, B. B.; NAIR, V.; PREISINGER, R.; SCHUSSER, B. Acquiring Resistance Against a Retroviral Infection via CRISPR/Cas9 Targeted Genome Editing in a Commercial Chicken Line. Frontiers in Genome Editing, V. 2, p.3. 2020.

HILL, W. G. Applications of Population Genetics to Animal Breeding, from Wright, Fisher and Lush to Genomic Prediction. Genetics, V. 196, 1-16. 2014.

HUANG, J., WU, S., BARRERA, J., MATTHEWS, K., PAN, D. The Hippo signaling pathway coordinately regulates cell proliferation and apoptosis by inactivating Yorkie, the Drosophila homolog of YAP. Cell, V.122, 421-434, 2005.

ISHINO, Y.; SHINAGAWA， H.; MAKINO, K.; AMEMURA， M.; NAKATA， A. Nucleotide sequence of the iap gene, responsible for alkaline phosphatase isozyme conversion in Escherichia coli, and identification of the gene product. Journal of Bacteriology, V. 169, 5429-5433. 1987.

JANSEN, R., EMBDEN, J.D.A.V., GAASTRA, W. and Schouls, L.M. Identification of genes that are associated with DNA repeats in prokaryotes. Molecular Microbiology, V. 43: 1565$1575,2002$.

JIA, J., ZHANG, W., WANG, B., TRINKO, R., JIANG, J. The Drosophila Ste20 family kinase dMST functions as a tumor suppressor by restricting cell proliferation and promoting apoptosis. Genes \& Development, V.17, 2514-2519, 2003.

JINEK, M.; CHYLINSKI, K.; FONFARA, I.; HAUER, M.; DOUDNA, J. A.; CHARPENTIER, E. A Programmable Dual-RNA-Guided DNA Endonuclease in Adaptive Bacterial Immunity. Science, V. 337, pp. 816-82. 2012.

JUSTICE, R. W., ZILIAN, O., WOODS, D. F., NOLL, M. AND BRYANT, P. J. The Drosophila tumor suppressor gene warts encodes a homolog of human myotonic dystrophy kinase and is required for the control of cell shape and proliferation. Genes \& Development, V. 9, 534-546, 1995. 
KANG, Y.; CHU, C.; WANG, F.; NIU, Y. CRISPR/Cas9 mediated genome editing in nonhuman primates. Disease Models \& Mechanisms, V. 12, nº10. 2019.

KASAP, C.; ELEMENTO, O.; KAPOOR, T. M. DrugTargetSeqR: a genomics- and CRISPRCas9-based method to analyze drug targets. Nature Chemical Biology, V.10, (8):626-8. 2014.

KISHIMOTO, K.; WASHIO, Y.; YOSHIURA, Y.; TOYODA, A.; UENO, T.; FUKUYAMA, H.; KATO, K.; KINOSHITA, M. Production of a breed of red sea bream Pagrus major with an increase of skeletal muscle mass and reduced body length by genome editing with CRISPR/Cas9. Aquaculture, V. 495, 415-427. 2018.

KOMOR, A. C.; KIM, Y. B.; PACKER, M. S.; ZURIS, J. A.; LIU, D. R. Programmable editing of a target base in genomic DNA without double-stranded DNA cleavage. Nature, $533,420-424.2016$.

KOO, D. B., KANG, Y. K., CHOI, Y. H., PARK, J. S., KIM, H. N., OH, K. B., SON, D. S., PARK, H., LEE, K. K., HAN, Y. M. Aberrant Allocations of Inner Cell Mass and Trophectoderm Cells in Bovine Nuclear Transfer Blastocysts1. Biology of Reproduction, V. 67, 487-492. 2002.

KOROTKEVICH, E.; NIWAYAMA, R.; COURTOIS, A.; FRIESE, S.; BERGER, N.; BUCHHOLZ, F.; HIIRAGI, T. The Apical Domain Is Required and Sufficient for the First Lineage Segregation in the Mouse Embryo. Developmental Cell, V. 40(3):235-247.e7. Feb, 2017.

LI, G.; ZHANG, X.; WANG, H.; MO, J.; ZHONG, C.; SHI, J.; ZHOU, R.; LI, Z.; YANG, H.; WU, Z.; LIU, D. CRISPR/Cas9 mediated integration of large transgene into pig potential safe harbor. BioRxiv, 722348. Aug, 2019.

LI, T., ZHAO, H., ZHAO, X., ZHANG, B., CUI, L., SHI, Y., LI, G., WANG, P., CHEN, Z. J. Identification of YAP1 as a novel susceptibility gene for polycystic ovary syndrome. Journal of Medical Genetics, V. 49, 254-257. 2012. 
LI, X.; HAO, F.; HU, X.; WANG, H.; DAI, B.; WANG, X.; LIANG, H.; CANG, M.; LIU, D. Generation of T $\beta 4$ knock-in Cashmere goat using CRISPR/Cas9. International Journal of Biological Sciences, V.15 (8):1743-1754. 2019.

LORTHONGPANICH, C., MESSERSCHMIDT, D. M., CHAN, S. W., HONG, W., KNOWLES, B. B., SOLTER, D. Temporal reduction of LATS kinases in the early preimplantation embryo prevents ICM lineage differentiation. Genes \& Development, V. 27, 1441-1446, 2013.

MADEIRA, F.; PARK, Y. M.; LEE, J.; BUSO, N.; GUR, T., MADHUSOODANAN, N.; BASUTKAR, P.; TIVEY, A. R N.; POTTER, S. C.; FINN, R. D.; LOPEZ, R. The EMBLEBI search and sequence analysis tools APIs in 2019. Nucleic Acids Research, V. 47, (W1):W636-W641. Jul, 2019.

MAÎTRE, J. L.; TURLIER, H.; ILLUKKUMBURA, R.; EISMANN, B.; NIWAYAMA, R.; NÉDÉLEC, F.; HIIRAGI, T. Asymmetric division of contractile domains couples cell positioning and fate specification. Nature, V. 536, (7616):344-348. Aug, 2016.

MAKAROVA, K. S.; GRISHIN, N. V.; SHABALINA, S. A.; WOLF, Y. I.; KOONIN, E. V. A putative RNA-interference-based immune system in prokaryotes: computational analysis of the predicted enzymatic machinery, functional analogies with eukaryotic RNAi, and hypothetical mechanisms of action. Biology Direct, V. 16, 1:7 2006.

MALI, P.; ESVELT, K. M.; CHURCH, G. M. Cas9 as a versatile tool for engineering biology. Nature Methods, V. 10, 957-963. 2013.

MALI, P.; LUHAN, Y.; ESVELT, K. M.; AACH, J.; GUELL, M.; DICARLO, J. E.; NORVILLE, J. E.; CHURCH, G. M. RNA Guided Human Genome Engineering via Cas9. Science, V. 339, Issue 6121, 823-826. 2013.

MANZANARES, M; RODRIGUEZ, TRISTAN A. Development: Hippo Signalling Turns the Embryo Inside Out. Current Biology, v. 23, n 13, R559-R561. 2013. 
MAUVIEL, A.; NALLET-STAUB, F.; VARELAS, X. Integrating developmental signals: a Hippo in the (path)way. Oncogene, V. 31, n 14, 1743-56. Apr, 2012.

MCEVOY, T. G.; COULl, G. D.; BROADBENT, P. J.; HUTCHINSON, J. S. M.; SPEAKE, B. K. Fatty acid composition of lipids in immature cattle, pig and sheep oocytes with intact zona pellucida. Journal of Reproduction and Fertility, V. 118, 163-170. 2000.

MENCHACA, A.; DOS SANTOS, P. C.; MULET, A. P.; CRISPO, M. CRISPR in livestock: From editing to printing. Theriogenology, V. 150, 247-254. 2020.

MENG, Z.; MOROISHI, T.; GUAN, K. L. Mechanisms of Hippo pathway regulation. Genes \& Development, V. 30, nº1, 1-17. Jan, 2016.

MUELlER, M. L.; COLE, J. B.; SONSTEGARD, T. S.; VAN EENENNAAM, A. L. Comparison of gene editing versus conventional breeding to introgress the POLLED allele into the US dairy cattle population. Journal of Dairy Science, V. 102(5):4215-4226. 2019.

NEVES, J. P.; MIRANDA, K. L.; TORTORELLA, R. D. Progresso científico em reprodução na primeira década do século XXI. Revista Brasileira de Zootecnia, V.39, p. 418. Brasília DF, 2010.

NISHIO, M.; KOICHI, H.; KOHICHI, K.; MASATO, S.; FUMIHITO, N.; SHUHEI, C.; KENSAKU, M.; SATOSHI, O. S.; YOUYI, D.; MASAAKI, T.; TAKUMI, M.; HIROKI, H.; JONATHAN, E.; NORIKAZU, Y.; HIROSHI, N.; KENTARO, N.; YUTAKA, H.; HIROSHI, N.; KOSHI, M.; MASAKI, M.; TAKEHIKO, S.; TAK, W. M.; TORU, N.; SATOSHI, I.; AKIRA, S. Cancer susceptibility and embryonic lethality in Mob1a/1b doublemutant mice. The Journal of Clinical Investigation, V. 122, 4505-4518, 2012.

NISHIOKA, N., INOUE, K., ADACHI, K., KIYONARI, H., OTA, M., RALSTON, M., YABUTA, N., HIRAHARA, S., STEPHENSON, R. O., OGONUKI, N., MAKITA, R., KURIHARA, H., KENSICKI, M. M., NOJIMA, H., ROSSANT, J., NAKAO, K., NIWA, H., SASAKI, H. The Hippo Signaling Pathway Components Lats and Yap Pattern Tead4 Activity to Distinguish Mouse Trophectoderm from Inner Cell Mass. Developmental Cell, V. 16, 398-410, March 17, 2009. 
NISHIOKA, N., YAMAMOTO, S., KIYONARI, H., SATO, H., SAWADA, A., OTA, M., NAKAO, K., SASAKI, H. Tead4 is required for specification of trophectoderm in preimplantation mouse embryos. Mechanisms of Development, Volume 125, Issues 3-4, 270 283. March-April 2008.

NIU, D.; WEI, H. J.; LIN, L.; GEORGE, H.; WANG, T.; LEE, I. H.; ZHAO, H. Y.; WANG, Y.; KAN, Y.; SHROCK, E.; LESHA, E.; WANG, G.; LUO, Y.; QING, Y.; JIAO, D.; ZHAO, H.; ZHOU, X.; WANG, S.; WEI, H.; GÜELL, M.; CHURCH, G. M.; YANG, L. Inactivation of porcine endogenous retrovirus in pigs using CRISPR-Cas9. Science, V. 357, Issue 6357, 1303-1307. 2017.

OLIVEIRA, C. B.; BORTOLI, E. C.; BARCELLOS, J. O. J. Diferenciação por qualidade da carne bovina: a ótica do bem-estar animal. Ciência Rural, V. 38, nº7, 2092-2096. 2008.

ORTEGA, M.S., KURIAN, J.J., MCKENNA, R., HANSEN, P. J. Characteristics of candidate genes associated with embryonic development in the cow: Evidence for a role for WBPI in development to the blastocyst stage. PLoS ONE, V. 12. (5): e0178041. 2017.

PALERMO, G.; RICCI, C. G.; FERNANDO, A.; BASAK, R.; JINEK, M.; RIVALTA, I.; BATISTA, V. S.; MCCAMMON, J. A. Protospacer Adjacent Motif-Induced Allostery Activates CRISPR-Cas9. Journal of the American Chemical Society, V. 139(45):1602816031. 2017.

PELAEZ, V.; SCHMIDT, W. A difusão dos OGM no Brasil: imposição e resistências. Estudos Sociedade e Agricultura, V. 8, nº 14. 2000.

PICCOLO, S., DUPONT, S., CORDENONSI, M. The Biology Of Yap/Taz: Hippo Signaling And Beyond. Physiological Reviews, V. 94: 1287-1312. 2014.

PINKERT, C. A. Transgenic Animal Technology, a laboratory handbook. Elsevier, third Edition, p. 714, 2014.

PINZON-ARTEAGA, C.; SNYDER, M. D.; LAZZAROTTO, C. R.; MORENO, N. F.; JURAS, R.; RAUDSEPP, T.; GOLDING, M. C.; VARNER, D. D.; LONG, C. R. Efficient 
correction of a deleterious point mutation in primary horse fibroblasts with CRISPR-Cas9. Scientific Reports, V. 10, n⿳0 7411, 2020.

PRASKOVA, M.; XIA, F.; AVRUCH, J. MOBKL1A/MOBKL1B phosphorylation by MST1 and MST2 inhibits cell proliferation. Current Biology, V. 18, $n^{\circ}$ 5, 311-21. ISSN 0960-9822 (Print), 0960-9822. Mar, 2008.

RAN, F. A.; HSU, P. D.; WRIGHT, J.; AGARWALA, V.; SCOTT, D. A.; ZHANG, F. Genome engineering using the CRISPR-Cas9 system. Nature Protocols, V. 8, 2281-2308. 2013.

SAKURAI, N., TAKAHASHI, K., EMURA, N., HASHIZUME, T., SAWAI, K. Effects of downregulating TEAD4 transcripts by RNA interference on early development of bovine embryos. Journal of Reproduction and Development, V. 63, 135-142. 2017.

SAWADA, A., KIYONARI, H., UKITA, K., NISHIOKA, N., IMUTA, Y., SASAKI, H. Redundant roles of Tead1 and Tead2 in notochord development and the regulation of cell proliferation and survival. Molecular and Cellular Biology, V. 28, 3177-3189. 2008.

SCHMIDT, M., GREVE, T., AVERY, B., BECKERS, J. F., SUlON, J., HANSEN H. B. Pregnancies, calves and calf viability after transfer of in vitro produced bovine embryos. Theriogenology, V. 46, 527-539. 1996.

SHAH, S. A.; ERDMANN, S.; MOJICA, F. J.; GARRETT, R. A. Protospacer recognition motifs: mixed identities and functional diversity. RNA Biology, V. 10, (5):891-9. May, 2013.

SHARMA, J.; MADAN, P. Characterisation of the Hippo signalling pathway during bovine preimplantation embryo development. Reproduction, Fertility and Development. Journal compilation. CSIRO 2019.

SHIMATANI, Z.; FUJIKURA, U.; ISHII, H.; MATSUI, Y.; SUZUKI, M.; UEKE, Y.; TAOKA, K.; TERADA, R.; NISHIDA, K.; KONDO, A. Inheritance of co-edited genes by CRISPR-based targeted nucleotide substitutions in rice. Plant Physiology and Biochemistry, V.131, 78-83. Oct, 2018. 
STADTMAUER, E. A.; FRAIETTA, J. A.; DAVIS, M. M.; COHEN, A. D.; WEBER, K. I.; LANCASTER, E.; MANGAN, P. A.; KULIKOVSKAYA, I.; GUPTA, M.; CHEN, F.; TIAN, L.; GONZALEZ, V. E.; XU, J.; JUNG, I. Y.; MELENHORST, J. J.; PLESA, G.; SHEA, J.; MATLAWSKI, T.; CERVINI, A.; GAYMON, A. I.; DESJARDINS, S.; LAMONTAGNE, A.; SALAS-MCKEE, J.; FESNAK, A.; SIEGEL, D. I.; LEVINE, B. I.; JADLOWSKY, J. K.; YOUNG, R. M.; CHEW, A.; HWANG, W.; HEXNER, E. O.; CARRENO, B. M.; NOBLES, C. I.; BUSHMAN, F. D.; PARKER, K. R.; QI, Y.; SATPATHY, A. T.; CHANG, H. Y.; ZHAO, Y.; LACEY, S. F.; JUNE, C. H. CRISPR-engineered T cells in patients with refractory cancer. Science, V. 367, Issue 6481. Feb, 2020.

STRUMPF, D.; MAO, C. A.; YAMANAKA, Y.; RALSTON, A.; CHAWENGSAKSOPHAK, K.; BECK, F.; ROSSANT, J. Cdx2 is required for correct cell fate specification and differentiation of trophectoderm in the mouse blastocyst. Development, V. 132(9), 2093-102. 2005.

SWIECH, L.; HEIDENREICH, M.; BANERJEE, A.; HABIB, N.; LI, Y.; TROMBETTA, J.; SUR, M.; ZHANG, F. In vivo interrogation of gene function in the mammalian brain using CRISPR-Cas9. Nature Biotechnology, V.33, 102-106. 2015.

TAN, G.; REN, L.; HUANG, Y.; TANG, X.; ZHOU, Y.; ZHOU, Y.; LI, D.; SONG, H.; OUYANG, H.; PANG, D. Isolation and culture of embryonic stem-like cells from pig nuclear transfer blastocysts of different days. Cambridge University Press, Zygote, V. 20, 347-352. 2011.

The future of food and agriculture - Trends and challenges. Rome. Food and Agriculture Organization of the United Nations - FAO. Rome, 2017. Disponível em: http://www.fao.org/3/a-i6583e.pdf. Acesso em 27 ago. 2020.

TRIBUlO, P., LEÃO, B. C. S., LEHLOENYA, K. C., MiNGOTI, G. Z., HANSEN, P. J. Consequences of endogenous and exogenous WNT signaling for development of the preimplantation bovine embryo. Biology of Reproduction, V.96 (6), 1129-1141. 2017. 
TSOI, M., MORIN, M., RICO, C., JOHNSON, R.L., PAQUET, M., GÉVRY, N., BOERBOOM, D. Lats 1 and Lats2 are required for ovarian granulosa cell fate maintenance. The FASEB Journal, V. 33, 10819-10832. 2019.

TU, Z.; YANG, W.; YAN, S.; GUO, X.; LI, X. J. CRISPR/Cas9: a powerful genetic engineering tool for establishing large animal models of neurodegenerative diseases. Molecular Neurodegeneration, V. 4, 10:35. Aug, 2015.

URNOV, F.; REBAR, E.; HOLMES, M.; ZHANG, S.; GREGORY, F. D. Genome editing with engineered zinc finger nucleases. Nature Reviews Genetics, V. 11, 636-646. 2010.

VACKOVA, I.; UNGROVA, A.; LOPES, F. Putative Embryonic Stem Cell Lines from Pig Embryos. Journal of Reproduction and Development, V. 53, Issue 6, 1137-1149. 2007.

VARELAS X. The Hippo pathway effectors TAZ and YAP in development, homeostasis and disease. Development, V. 141(8), 1614-26. Apr, 2014.

VILARINO, M.; RASHID, S. T.; SUCHY, F. P.; MCNABB, B. R.; MEULEN, T. V. D.; FINE, E. J.; MURSALIYEV, S. A. N.; SEBASTIANO, V.; DIAB, S. S.; HUISING, M. O.; NAKAUCHI, H. J.; ROSS, P. CRISPR/Cas9 microinjection in oocytes disables pancreas development in sheep. Scientific Reports, V. 7, nº. Dec, 2017.

VORA, S.; TUTTLE, M.; CHENG, J.; CHURCH, G. Next stop for the CRISPR revolution: RNA-guided epigenetic regulators. The Febs Journal, V. 283. Special Issue: CRISPR/Cas9 Gene Editing, 3181-3193. 2016.

WANG, H., DEY, S. K. Roadmap to embryo implantation: clues from mouse models. Nature Reviews Genetics, V. 7, 185-199. 2006.

WIEDENHEFT, B.; STERNBERG, S. H.; DOUDNA, J. A. RNA guided genetic silencing systems in bacteria and archaea. Nature, V. 482, 331-338. 2012.

YAGI, R., KOHN, M. J., KARAVANOVA, I., KANEKO, K. J., VUllHORST, D., DEPAMPHILIS, M. L.; BUONANNO, A. Transcription factor TEAD4 specifies the 
trophectoderm lineage at the beginning of mammalian development. Development, V. 134, 3827-3836, 2007.

YAGI, R., KOHN, M. J., KARAVANOVA, I., KANEKO, K. J., VUllHORST, D., DEPAMPHILIS, M.L., BUONANNO, A. Transcription factor TEAD4 specifies the trophectoderm lineage at the beginning of mammalian development. Development, V. 134, 3827-3836. 2007.

YEH, Y. C.; KINOSHITA, M.; NG, T. H.; CHANG, Y. H.; MAEKAWA, S.; CHIANG, Y. A.; AOKI, T.; WANG, H. C. Using CRISPR/Cas9 mediated gene editing to further explore growth and trade-off effects in myostatin-mutated F4 medaka (Oryzias latipes). Scientific Reports, V. 7, 11435. 2017.

YOUNG, R. A. Control of the embryonic stem cell state. Cell, V. 144, 940-954, 2011.

YU, F. X.; GUAN, K. L. The Hippo pathway: regulators and regulations. Genes \& Development, V. 27, nº 4, 355-71. Feb, 2013.

YUAN, T.; ZHONG, Y.; WANG, Y.; ZHANG, T.; LU, R.; ZHOU, M.; LU, Y.; YAN, K.; CHEN, Y.; HU, Z.; LIANG, J.; FAN, J.; CHENG, Y. Generation of hyperlipidemic rabbit models using multiple sgRNAs targeted CRISPR/Cas9 gene editing system. Lipids in Health and Disease, V. 18, nº 69. March, 2019.

ZHAO, B., LI, L., TUMANENG, K., WANG, C. Y., GUAN, K. L. A coordinated phosphorylation by Lats and CK1 regulates YAP stability through SCF (beta-TRCP). Genes \& Development, V. 24, $\mathrm{n}^{\circ}$ 1, 72-85. Jan, 2010.

ZHAO, B.; WEI, X.; LI, W.; UDAN, R. S.; YANG, Q.; KIM, J.; XIE, J.; IKENOUE, T.; YU, J.; LI, L.; ZHENG, P.; YE, K.; CHINNAIYAN, A.; HALDER, G.; LAI, Z. C.; GUAN, K. L. Inactivation of YAP oncoprotein by the Hippo pathway is involved in cell contact inhibition and tissue growth control. Genes \& Development, V. 21, nº 21, 2747-61. ISSN 0890-9369 (Print), 0890-9369. Nov, 2007. 
ZU, Y.; TONG, X.; WANG, Z.; LIU, D.; PAN, R.; LI, Z.; HU, Y.; LUO, Z.; HUANG, P.; WU, Q.; ZHU, Z.; ZHANG, B.; LIN, S. TALEN-mediated precise genome modification by homologous recombination in zebrafish. Nature Methods, V.10, 329-33. Feb, 2013. 


\section{ANEXOS}

8.1 Declaração de uso - Conteúdo científico

Faculdade de Medicina Veterináris e Zootecria, Universidade de São Paulo, Departamento de Reprodução Animal (VRA), Sส̄o Paulo - SP.

\section{DECL_ARACÃO DE USO - CONTEÚDO CIENTIFICO}

São Paulo, 09 de novembro de 2020.

Declaramos para os devidos fins, que o artigo de revisão ip̉titulado: "Sistema CRISPR/Cas9 e suas aplicações na cadeia produtiva animal" (CRISPR/Cas9 system and tis applications in the animat production chagn), submetido à publicaçào em revista nacional, durante o periodo do curso de mestrado da aluna Caroline Pereira da Costa $\mathrm{N}^{\mathrm{N}}$ USP: 10934539), nẫo será utilizado en outra dissertação ou tese, sendód de uso exclusivo para a presente dissertaçằ de mestrado.

Declaramos ainda que a primeira autora do artigo de revisła é a aluna responsável por esta dissertação. A submissăo do conteúdo foi realizada em uma revista nacional e segue aguardando o parecer até está data.

Cientes e de acordo com o exposto acima:

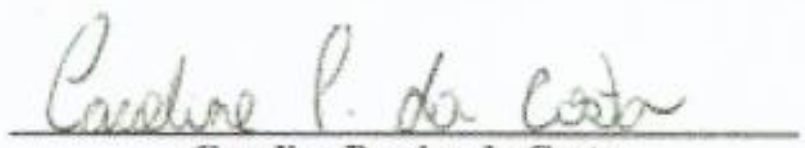

Caroline Pereira da Costa

$1^{\text {2 Autora }}$

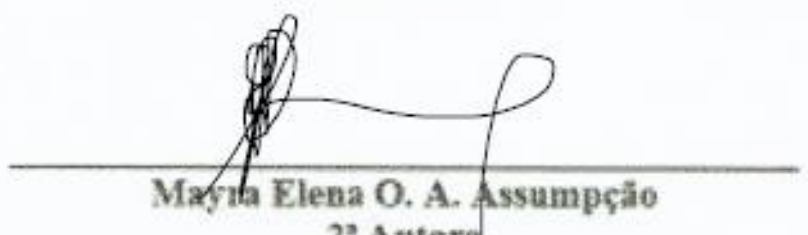

$2^{3}$ Autors

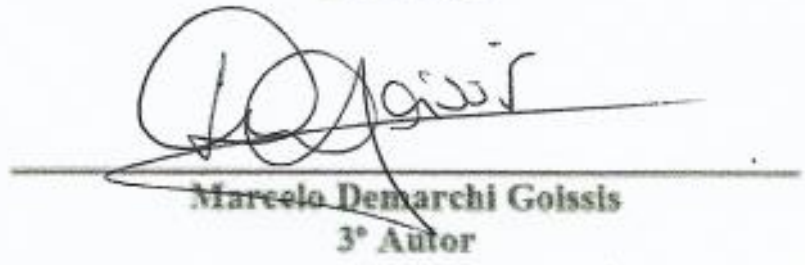

